\title{
An evolutionary and ecological perspective of Amazonian Hylaea species of Hymeneae (Leguminosae: Caesalpinioideae)
}

\author{
JEAN H. LANGENHEIM (*) \\ YIN-TSE LEE (*) \\ Susan S. Martin (*)
}

\begin{abstract}
The resin-producing genus Hymenaea has an amphi-Atlantic distribution with 13 species being Neotropical and one occurring along the eastern coast of Africa. Present evidence suggests an African origin for the genus with migration across the Atlantic occurring during the Early Tertiary when the continents were closer and rainforest vegetation was considerably more widely distributed than today. The center of its Neotropical distribution is the Amazonian hylaea, although within its extensive range from $23^{\circ} \mathrm{N}$ to $26^{\circ} \mathrm{S}$ it is found in all major ecosystem types. The taxonomy, breeding structure, ecology and resin chemistry of the 9 Hymenaea species and 6 varieties occurring in tho Amazonian and historically-related Brazilian Atlantic coastal humid evergreen forests are discussed as well as the possible evolution of these species in response to postulated drying trends beguen in Mid Tertiary times and during wet-dry oscillations in the Pleistocene.
\end{abstract}

\section{INTRODUCTION}

Evolutionary interest in the leguminous genus Hymenaea (Caesalpinioideae, Detarieae(i) was initiated by the discovery that fossil resin (amber) from Mexico, Colombia and Brazil was derived from this source (Langenheim, 1966. 1967). Subsequently a world-wide investigation of the botanic source of amber in relation to present-day resin producers led to the conclusion that copious production of resin was predominantly a tropical phenomenon (Langenheim, 1969). Thus focussing study on a tropical leguminous genus, such as Hymenaea, provides an opportunity not only to analyze the change in the chemistry of a resin through time, but also to investigate a member of a family which constitutes one of the most important elements of tropical rainforest ecosystems. Ultimately, it is hoped that an analysis can be made regarding the role thai tropical environmental conditions play in the synthesis of the resin and the possible ecological significance of resins within tropical ecosystems. In both ecological and evolutionary contexts Hymenaea is particularly interesting because species of the genus appear to have radiated from a rainforest center into a wide variety of ecosystems of drier tropical habitats.

The genus has 14 presently-recognized species and 12 varieties (Lee, 1973). Its range is amphi-Atlantic, although 13 species are Neotropical with their distribution centered in the Amazon Basin but extending from $23^{\circ} \mathrm{N}$ in central Mexico, throughout the West Indies and to $26^{\circ} \mathrm{S}$ in South America, occurring in all countries except Chile and Uruguay. The one African species is distributed along the coast of eastern Africa (Kenya, Tanzania and Mozambique) and the offshore islands of Zanzibar, Madagascar, Mauritius and the Seychelles, and was only recently returned to Hymenaea from the genus Trachylobium (Langenheim \& Lee, 1973).

On the basis of inflorescence, flower and fruit characters, two taxonomic sections of the genus may be recognized (Langenheim and Lee. 1973; Lee, 1973; Fig. 1). Sect. Trachylobium is characterized by a long-paniculate inflorescence with small flowers and oval to oboval fruit.

(*) - Division of Natural Sciences, University of California. Santa Cruz, California.

(1) - In previous work (Martin, Langenheim and Zavarin, 1972; Langenheim, 1973) we have used the tribal designation of Cynometreae Benth. (1840) emend. Léonard (1957). Recently Heywood (1971) has presented de Candolle's (1825) name Detarieae which has priority over Bentham's name Cynometreae. 


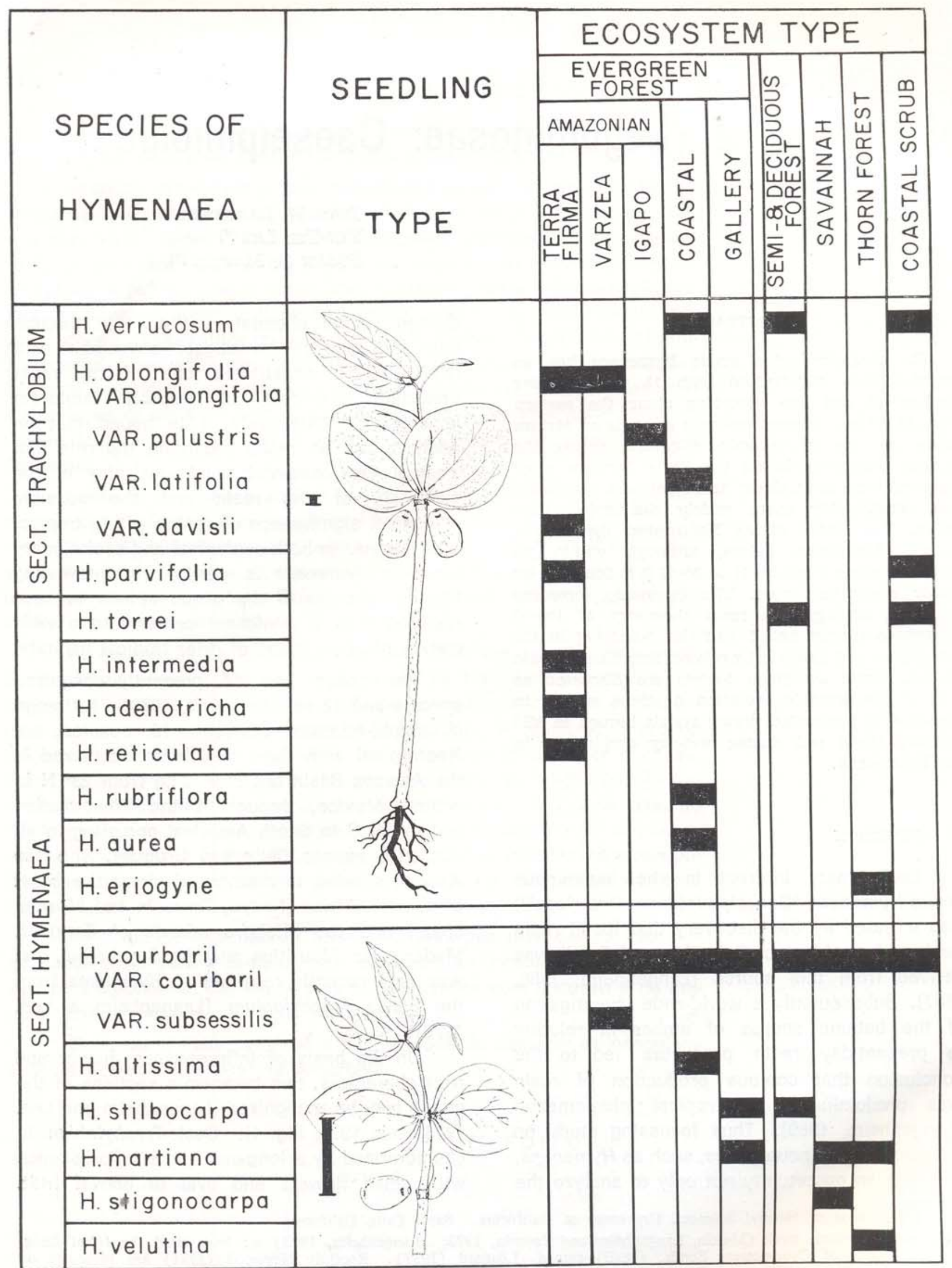

Fig. 1 - Distribution of Hymenaea in different ecosystem types with taxonomic sections and ecological groups based on seedling types indicated. 
In sect. Hymenaea the inflorescence is densely corymbose with medium to large flowers and generally large rhomboidal to oblong fruits.

On the basis of seedling characters, Hymenaea may be divided into two other groups; these classes segregate the species ecologically into those occurring in the evergreen forest (hylaea) habitats and those in the drier forest, savannah and semi-desert thorn shrub habitats (Fig. 1). In species primarily found in the evergreen forest habitats, there is a short primary internode between the cotyledon attachment and the two primary leaves; in contrast, the extra-evergreen forest habitat species have a relatively long internode.

This paper will cover the 9 species of Hymenaea which occur in evergreen rainforests, with emphasis placed upon those presently occurring within the Amazonian hylaea. Thus most of the species to be discussed fall into the ecological group which includes sect. Trachylobium and part of sect. Hymenaea (Fig. 1). Five species $(H$. oblongifolia varieties oblongifolia Huber and palustris Lee and Lang., $H$. parvifolia Ducke, $H$. reticulata Ducke, $H$. adenotricha Ducke and $H$. intermedia Ducke) are restricted to the Amazon Basin. Hymenaea oblongifolia var. davisii Lee and Lang. occurs in central Guyana. Hymenaea courbaril L. has essentially the distribution of the entire genus but variety subsessilis Ducke is restricted to the central Amazon Basin. Two species $(H$. rubriflora Ducke and H. aurea Lee and Lang.) and H. oblongifolia var. latifolia Lee and Lang. are distributed in the Brazilian Atlantic coastal rainforests from Pernambuco to Bahia. Hymenaea eriogyne Benth. occurs in forest islands in the caatinga of northeastern Brazil. These Atlantic coastal and northeastern Brazilian species are probably relicts from Early Tertiary times when the Amazonian-type forest had a more southerly distribution.

Hymenaea has many characters in common with the abundant resin-producing genus Guibourtia which occurs most frequently in West Africa but which has outposts in eastern Africa." It also has been hypothesized that the extremely diverse, Pantropical genus Cynometra may be the parental stock for genera such as Hymenaea and Guibourtia (Langenheim, 1973).
The closeness of relationship of Hymenaea to these African genera adds evolutionary and phytogeographic interest.

\section{ENVIRONMENTAL AND FLORISTIC PATTERNS OF THE SOUTH AMERICAN HYLAEA}

General characterization of the environmental and floristic variation within the hylaea is important to our interpretation of the ecological relations of Hymenaea species and their evolution. "Hylaea" is a cerm presented by Humboldt $(1807,1814-1825,1852)$ to refer to the South American equatorial rainforest but now is more commonly used by plant geographers to refer to all equatorial evergreen forests (Aubreville, 1961; Richards. 1966). The hylaea of South America covers more than 6 million square kilometers, i.e., most of the Amazon Basin, the basins of the upper Orinoco, and drainages in Guyana, Surj. nam and French Guiana as well as the basins of the lower Tocantins, including the Rio Pará and small rivers of Atlantic drainage eastward to the Rio Pindaré in Maranhão (Fig. 2). Evergreen forest extends along the eastern coast of Brazil from Pernambuco to Parana; however, the area in southern Bahia and and northern Espirito Santo is considered truly hylaea-type vegetation and has been called "Hylaea Bahiana" (Andrade-Lima, 1953).

Thus natural limits of the hylaea are set in the east by the Atlantic Ocean and in the west by the Andes, except for a Pacific coastal extension in Ecuador and Colombia (Fig. 2). Its northern limits in Colombia and Venezuela and its southern boundary in Bolivia and central Brazil appear to be controlled by climatically drier areas and hence a gradual transition occurs to drier forest and savannah-type ecosystems (Soares, 1953). In the Amazon Basin proper the forest is nearly continuous in the west but areas of open savannah with a non-hylaea flora are scattered in the central and eastern regions. Although our discussion will be centered upon species of Hymenaea within the Amazon Basin, they are distributed throughout the hylaea. Additionally, an understanding of the evolution of the genus is very closely tied to the history of both the South American and African equatorial rainforests through Tertiary and Pleistocene times. 


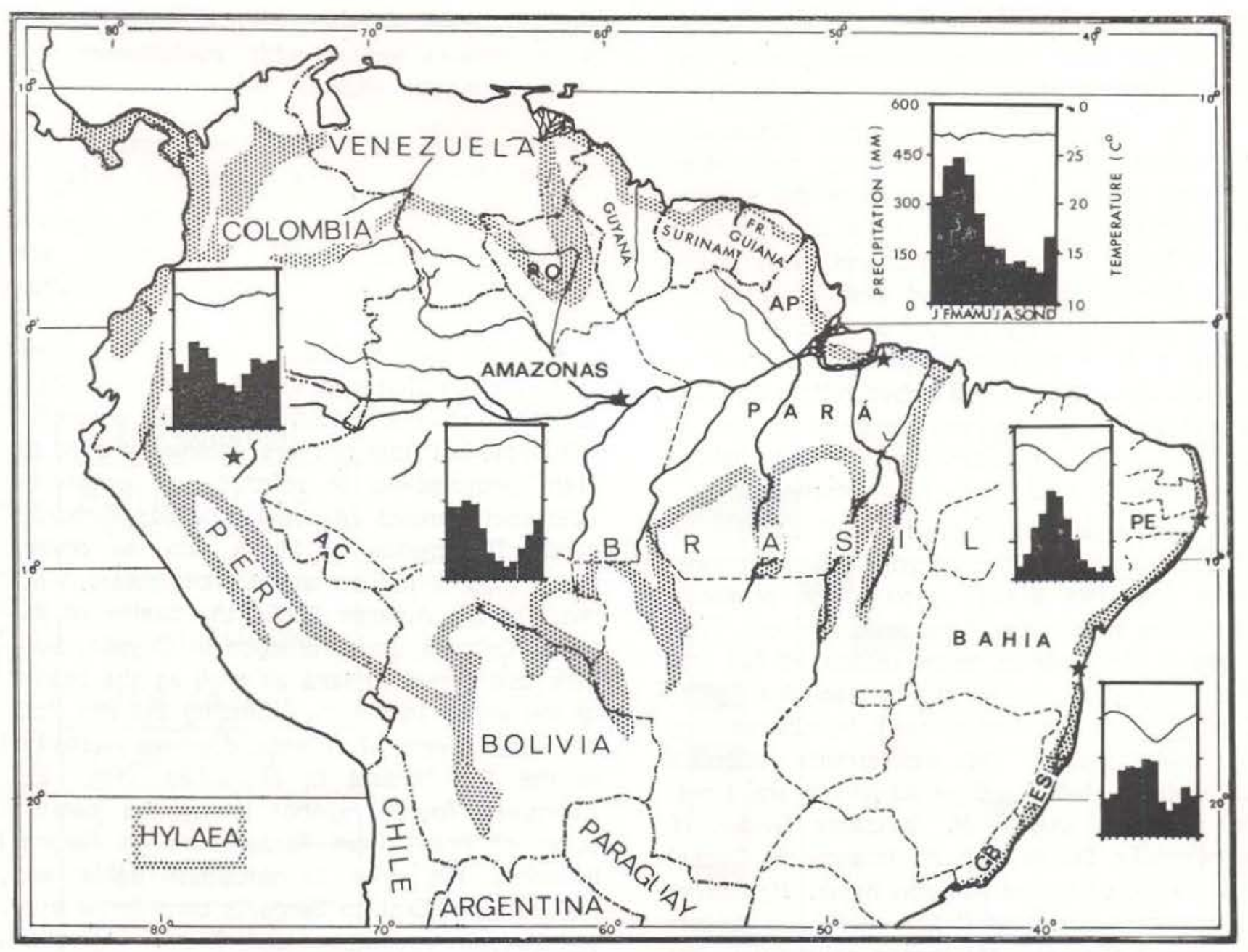

Fig. 2 - Vegetation map of the South American hylaea with insets showing monthly average rainfall and temperature conditions for typical stations in different floristic regions. Climatic data obtained from Ministerio da Agricultura do Brasil, Normais Climatológicas (1968) and U.S. Dept. of Commerce, Monthly Climatic Data for the World (Jan. 1956Dec. 1969). "Indicates the location of the weather stations: Iquitos in Peru; Manaus, Amazonas; Belém, Pará; Recife, Pernambuco; Ilhéus, Bahia in Brazil.

Because of lack prominent physiographic differences and similarity in physiognomy of the hylaea vegetation, the Amazon and adjacent basins have often been characterized by biologists as a "vast uniform habitat" (Haffer, 1969; Vanzolini and Williams, 1970; Vuilleumier, 1971), an impression that has considerably influenced evolutionary interpretations. "Uniformity of habitat" is, of course, relative to whatever group of organisms is being discussed. From the viewpoint of a botanist, the differences in both annual and seasonal precipitation patterns and soil types, which are reflected in significant floristic and vegetational variability, dispel the idea of uniformity. In fact, emphasis is shifted toward understanding the degree and nature of the variability.
Three major precipitation regimes may be recognized in Amazonia based on the total annual amount and seasonality (Sombroek, 1966; Sioli, 1968). Highest annual rainfalls (over $3000 \mathrm{~mm}$ annually) occur in the extreme east (Amazonian Estuary) and west (drainages of the Rio Solimões, Japura and middle and upper Rio Negro). The lower Amazon (between the Rio Trombetas and Xingu) receives only $1500-2000 \mathrm{~mm}$ annually, whereas the central Amazon (from the Rio Trombetas westerly to the eastern Solimões) and an eastern strip in Pará and Amapá are intermediate with 2000-2500 $\mathrm{mm}$. The eastern and central areas are characterized by relatively heavy "winter" rains (December-June) and a relative dry period in the "summer" (July-November). In the western 
part of the basin the precipitation is more well distributed throughout the year, although two relatively short dry seasons may occur in certain areas from February to March and June to August.

In contrast to precipitation regimes, temperatures and relative humidity are relatively constant in Amazonia. The mean annua! temperature varies from 23.5 to $26.9^{\circ} \mathrm{C}$. The relative humidity is high with the annual mean varying from $73-94 \%$. In the central part of Amazonia the mean values everywhere above $80 \%$. The constancy of this high humidity, even during dry seasons, means lesser transpiration rates than would otherwise be expected and may be of considerable importance to the development of the vegetation.

In addition to the importance of the patterns of precipitation, temperature and humidity in determining moisture availability to plants, the degree of flooding is of major consequence. In the igapó (swamp forest) the soil never dries out, in the várzea the forest is periodically inundated, whereas on the dry upland terra firme the forests are never flooded. An igapó habitat can also occur on marshy banks of forest streams in an area otherwise characterized as várzea or terra firme. The lowlands of the coastal belt and the Amazonian estuary are influenced by tides; the lowest land (daily flooded) is related to igapó, whereas higher land (flooded only by spring tides) resembles the várzea of other areas. Terra firme and várzea are not so easily separated in the western part of Amazonia as in the eastern. The western várzea includes many islands of higher, rarely flooded "restingas" where typical várzea forest is mixed with various species usually growing on terra firme. In addition, terra firme of western Amazonia is not a continuous upland interrupted only by igapó of some streams, as is usual in the more eastern part of the hylaea. More often it consists of an undulating terrain where strips of upland alternate with depressions which are often marshy and flooded by rain water.

Over $98 \%$ of the hylaea occurs on terra firme, which consists in central Amazonia of deposits laid down in an enormous PliocenePleistocene inland lake that extended from the foot of the Andes to the Atlantic Ocean (Sombroek, 1966). Although the soils were derived from relatively uniform lithologic sources (granites and gneisses) from the Guyana Shield in north and the central Brazilian Upland in the south, soils vary considerably and are a dominant influence in controlling local floras (Ducke and Black, 1953; Sombroek, 1966). The soil types range from predominantly sandy to some compact clay loams, which tend to be both acid and infertile, to small areas of fertile man-created "terra preta" soils.

The soils of the várzea are quite different from those of the central and lower Amazonian terra firme. At the end of the Pleistocene, the rise in ocean level drowned the river valleys of lower Amazonia and the rivers began to fill with sediments brought from the headwater region, forming new floodplains related to the altered river level (Sioli, 1968, 1973). The soils are fertile (in contrast to those of the terra firme) both because of their being derived from diverse bedrock types in the Andes and from the annual renewal of sediments on them. Despite more fertile soils, the várzea forest is not as rich in species as is the terra firme forest. Along the Lower Amazon the várzea forest is restricted to the river banks (with the shallow várzea lakes being occupied by grassland or "várzea savannah"). Although a great many várzea forest species occur throughout the Amazon Basin, further west one goes the richer in the species the varzeas become. Hera the vast várzea grassland and savannahs are missing and the forest extends into the water of the várzea lakes and igapó (Sioli, 1968, 1973). Also, many species grow in the várzea here that elsewhere grow only on the upland terra firme (Ducke and Black, 1953).

The hylaea flora is best known along the navigable rivers with most upland areas between the rivers being poorly collected. Therefore, it is difficult to establish meaningful phytogeographic regions of the hylaea based upon our present knowledge of the flora. However, the preliminary zonal characterization by Ducke and Black (1953) is useful for ecological and evolutionary considerations. They point out that longitude plays a more important role than latitude in composition of 
the flora. There thus are three main longitudinally determined zones with latitudinal subdivisions (Fig. 3). Although there is some general correlation of the floristic zones with the three major climatic areas, the boundaries are not strongly coincident, indicating that the present floristic patterning is due to complex historical factors and edaphic as well as climatic conditions.

The Eastern Zone, subdivided into Northeast and Southeast sections, extend westward from the estuary to the Rio Xingu and eastern side of the Trombetas basin. The coastal area from Maranhão northward to French Guiana and Surinam is characterized by open campos (grasslands and savannahs) - the most extensive areas lying in the eastern half of the island of Marajó and in the Territory of Amapá. The Northeast comprises the hill country of the middle and upper courses of the rivers between the Amazon and the Essequibo, and the lower Amazonian tributaries. It is the most vegetationally heterogeneous part of the hylaea, often with the rainforest here being substituted by a summer-dry forest of lower trees or shrubland resembling the cerrado of central Brazil. In the areas northeast of Obidos and from Monte Alegre to Almeirim there are relatively large areas of grassland with scattered trees or densely ccivered with shrubs. Some of this grass and savannah area may result from agricultural colonies and the continuing grazing of cattle (Sioli, 1973). Ducke and Black (1953), however, have pointed out that islands of seasonally dry forest in the "hill campos" of Monte Alegre contain endemic species not characteristic of the hylaea flora. The Southeastern hylaea includes the basin of the Tocantins, with little know about the flora of the upper courses of

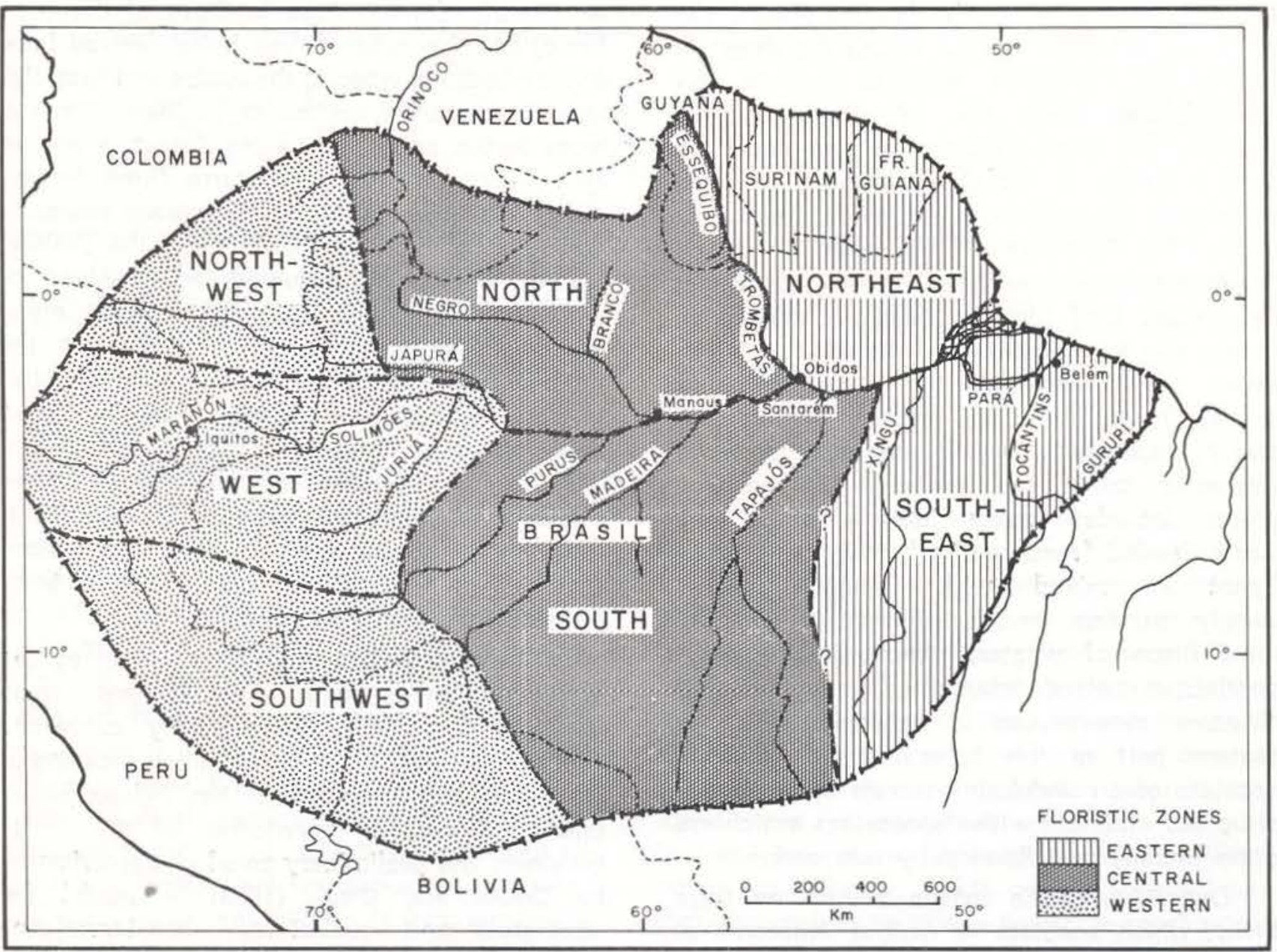

Fig. 3 - Floristic zones of the Amazonian hylaea as described by Ducke and Black (1959). Map drawn as constructed by Sombroek (1968). 
the smaller tributaries of Pará estuary, both sides of the Tocantins and that of the headwaters of the Gurupí. Little also is known of possible affinities of this Tocantins flora with that of the Xingu. Ducke and Black. however, suggest that due to more uniform environmental conditions, the flora here may not be as rich in species as that of the Northeastern section. This Eastern Zone often contains the western limits of many species common throughout the coastal region.

The Central Zone is divided into Northern and Southern sections. The Northern hylaea comprises the basin of ti.e Rio Negro (except the upper Rio Branco) the basin of the upper Orinoco, the eastern part of the Rio Japurá and the western part of the Trombetas basin. The flora of southwestern Guyana is related to it. The hylaea reaches its maximum diversity in number of genera and species, as well as endemics, in this area. It also appears to be a center of evolution for the Caesalpinioideae, with this group being the dominant forest element. Ducke and Black (1953) suggest that the floristic diversity in this section is probably related to the variety of ecological conditions, greater than any other other part of the hylaea. Here one encounters the highest mountains. such as Serra Curicuriari. The rocky tops of many of these serras are covered with shrubby vegetation which unfortunately has not been well collected. Also present in the flora of the Rio Negro basin are extensive areas of "caatinga", shrubs and low trees which occur on an upland silica soil with acid humus in regions with heavy rain throughout the year. The variety of species in these caatingas exceeds that of any other formation in any part of the hylaea. Almost all larger trees of the caatinga also grow in the virgin rainforest of the vicinity. However, the Amazonian caatinga has no close affinities with any other forest type and particularly little with the grasslands and open savannahs. "Campinas", open spots in the virgin forest on marshy soil composed of white sand and black humus, are also particularly well represented in this section". Floras of clearings are sometimes called campinas, and large campinas are sometimes called campos. However, the flora of the campina (as defined by Ducke and Black,
1953 ) is distinguished by its great variety of woody species representing a genuine, highly specialized part of the hylaea flora.

The Southern section of the Central Zone hylaea includes the whole basin of the Tapajós and the eastern tributaries of the Madeira. This section apparently approaches the Northern hylaea in richness of species. A larger number of species coming from western Amazonia seem to reach their eastern limit here, however, than in the Northern section.

The Western Zone of the hylaea is an immense plain occupying both sides of the upper Amazon (called Solimões in Brazil, Marañón in Peru). The eastern limit of the flora is uncertain, but the flora on both sides of the lower Solimões is more allied to that of the middle than that of the upper Amazon. The Western hylaea also has caatinga as does an area of the upper Rio Negro. The Northwestern section, as well as the partly mountainous transition zone to the flora of the middle Orinoco basin, belongs entirely to Colombia. The Southwestern section in Brazi! is represented by Acre, which includes numerous southern extra-Amazonian elements.

Ducke and Black (1953) point out that the distribution of many species follows one of several patterns: 1) distributed generally throughout Amazonia (mainly várzea species), 2) restricted to the longitudinally defined zones or sections within them, 3) occurring in the Eastern and Western zones but not in the Central zone. Again these facts tend to emphasize the heterogeneity of the environmental and resulting floristic and vegetational conditions of the hylaea, and again should dispel any concept of a "vast uniform habitat", at least with regard to the distribution of higher plants.

The evergreen forest of the Atlantic coastal plain has much in common climatically and floristically with that of the Amazonian region. It has been assumed that the Atlantic coastal forest, extending today from Pernambuco to the region around Rio de Janeiro, was connected with that of the Amazon Basin during at least the early Tertiary. Palentological (Menéndez, 1969; Simpson, 1969), floristic (Ducke, 1949; Andrade-Lima, 1953; Rizzini, 1963, 1967) and faunistic (Vanzolini and Williams, 1970) evidence 
supports this view. Floristically, Rizzini (1967) has pointed out that 277 genera occur in both Amazonian and Atlantic forests. Usually a genus which is represented by one or few species in the Atlantic forest has several to many in the Amazonian hylaea. Of particular interest is the region in southern Bahia and northern Espirito Santo, which has such an unusually high proportion of Amazonian hylaea species that it is called "Hylaea Bahiana" (Andrade-Lima, 1953). Andrade-Lima also felt that the high $(2000 \mathrm{~mm}$ or more), welldistributed rainfall in this area was probably an important factor in maintaining a similarity in both flora and physiognomy of this hylaea with much of the Amazonian hylaea.

MORPHOLOGIC DISTINCTIONS AND DISTRIBUTION OF THE HYLAEA SPECIES OF HYMENAEA

We will point out the prominent morphologic features that distinguish species of Hymenaea and discuss their habitats and distribution as a basis for evolutionary and ecological interpretation. A synoptic key is provided (appendix) to aid in identification of these species.

The earliest work on the Amazonian species of Hymenaea was done by Jacques Huber (1909), the first director of the Museu Goeldi in Belém, Pará. This beginning was followed by more extensive collection and description by Adolphe Ducke (1935, 1939, 1949), the indefatigable investigator of Brazilian legumes who collected both in the Amazon and Atlantic coastal forests. Additional hylaea species have been described from Guyana, the caatinga of northeastern Brazil, and the Brazilian coastal evergreen forest.

\section{Hymenaea oblongifolia Huber}

(Bol. Mus. Paraense Hist. Nat. 5: 386, 1909)

Hymenaea oblongifolia (sect. Trachylobium) is a polytypic species which probably constitutes the primitive stock for the evolution of Hymenaea in the New World (Langenheim and Lee, 1973)? The four recognized varieties (Lee and Langenheim, 1973) are separated morphologically by foliar and floral characters and are isolated ecologically by different habitats. Hymenaea microcarpa (Huber, 1910) for which no description has been published, is considered synonymous with $H$. oblongifolia (Ducke, 1939).

Hymenaea oblongifolia var. oblongifolia is distinguished by its narrowly oblong, glabrous leaflets and clawed to subclawed petals. This variety has one of the widest ranges of the Hymenaea species restricted to the Amazon and adjacent basins. Its distribution pattern (Fig. 4) conforms to high annual rainfall areas (more than $2500 \mathrm{~mm}$ ) in the eastern and western parts of the hylaea; it is conspicuously absent in the central drier areas (annual rainfall less than $2500 \mathrm{~mm}$ ). It is characteristic of the várzea alta (its common name being "jutahy de várzea"), but in the Western Zone (Fig. 3) also occurs along streams on terra firme clay soils. As was pointed out previously, however, it is more difficult to distinguish the terra firme and varzea habitats in the western Amazon than in the eastern. Variety oblongifolia has been most commonly collected in the eastern Amazon where it is relatively frequent on the várzea of the Rio Guamá, the llha do Marajó. and in all parts of the Furos de Breves in Pará. It also has been collected in the Trombetas basin but as yet has not been reported from the southeastern Amazon. It has been collected over a wide area in the western zone from the Rio Japurá (Caquetá in Colombia), along the Rio Solimões, and in the south on the Rio Madeira and Rio Juruá. Schultes (1953) has pointed out that it is associated with Cretaceous outliers of "the Venezuela-Guyana land mass".

Hymenaea oblongifolia var. palustris is distinguished by the dense, golden-brown tomentose hairs underneath the leaflets, and by small flowers with almost subsessile petals. Its wood is much harder than that of variety oblongifolia. Variety palustris has essentially the same distribution pattern as variety oblongifolia (Fig. 4), occurring in the same high rainfall regions of the extreme eastern and western parts of the Amazon Basin, although it is less frequent or at least has been less collected. Ecologically, variety palustris, as its name implies, occurs principally in the swamp forest or igapó (its common name being "jutahy de igapó"), found along the inundated margins of rivers (Fig. 5). It 


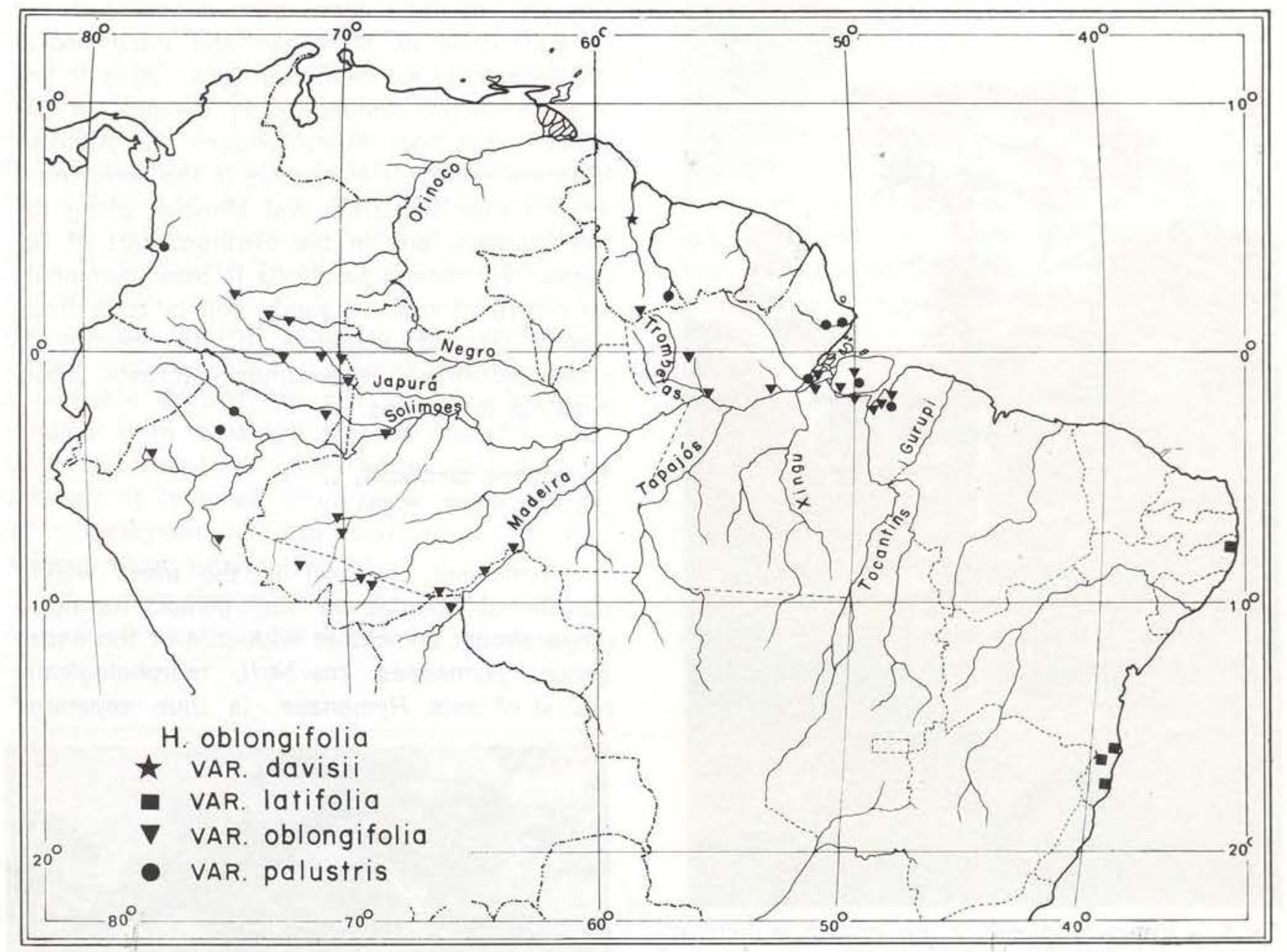

Fig. 4 - Distribution of $H$. oblongifolia and its varieties davisii, latifolia and palustris.

occurs particularly in igapós of the western part of llha de Marajó, near Belém, Pará, and along rivers in Amapá. In the western zone it has been collected twice along rivers near Iquitos, Peru. Also it has been reported once from the Rio Yurumangui, along the Colombian coast. This is the only known location for Hymenaea occurring in the hylaea west of the Andes.

Hymenaea oblongifolia var. davisii is distinguished by its narrowly falcate and longacuminate leaflets, and its lanceolate and subsessile petals. This variety is known from only two collections, each from along a river in the drainage of the Essequibo River, Guyana (Fig. 4). It is commonly called "courabarie", "locust", or "simiri", names which may also be applied to $H$. courbaril.
Hymenaea oblongifolia var. latifolia is distinguished by its broadly-oblong leaflets (having a length: width ratio of about 2 as compared with 3 in the other varieties), and by its distinctly clawed petals. Unlike the three varieties just described, variety latifolia is restricted to the Atlantic coastal evergreen forests (Fig. 4). Although it is isolated from the Amazonian hylaea, the affinity of variety latifolia with the other three varieties is indicated by similarities in both floral and fruit characters. In Pernambuco it has been foound along the Rio Gurjau, while in southern Bahia it occurs both along rivers and more commonly in forests on the uplands (Fig. 8). Its common names include "jatobá burundanga" and "jatobá farinheira". 


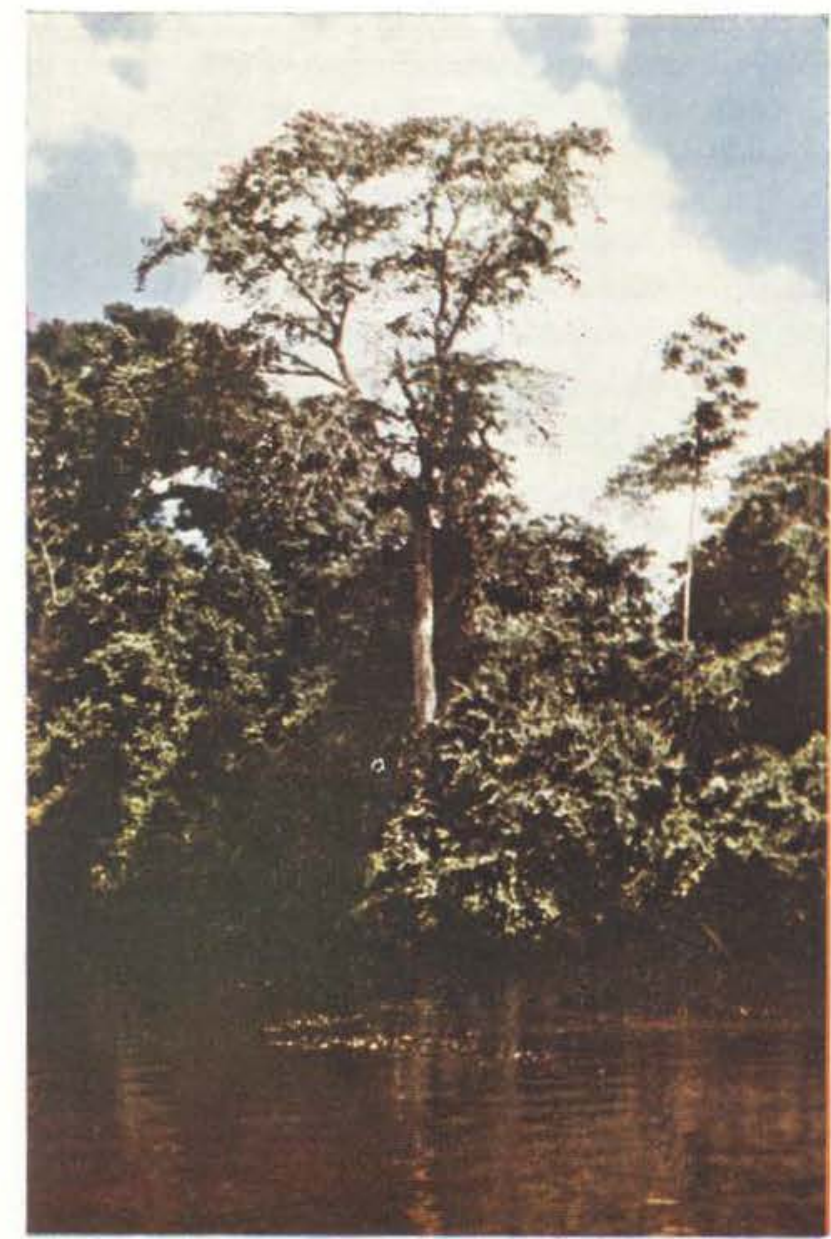

Fig. 5 - Hymenaea oblongifolia, var. palustris in riverside igapó, Rio Araguari, Amapá.

\section{Hymenaea parvifolia Huber}

(Bol. Mus. Paraense Hist. Nat. 5: 385-386, 1909)

Hymenaea parvifolia, the only other Amazonian species belonging to sect. Trachylobium, can be separated from closely related species such as $H$. oblongifolia by the generally small, short, falcate leaflets; the narrowly oblanceolate and rarely clawed petals which are densely pilose on the upper sides; and the small, ovoid, ovoid, often one-seeded fruit. The smallness of the fruit has led to the names "jutaí pororoca" and "jutaí pequeno". Two names $(H$. microphylla B. Rodr. and $H$. pororoca Huber] have appeared in the literature without published descriptions, but are considered synonyms of $H$. parvifolia (Ducke, 1915).

In contrást to $H$. oblongifolia, $H$. parvifolia occurs primarily in the drier eastern and central areas with annual rainfall less than $2500 \mathrm{~mm}$
(Fig. 7). In the eastern zone it occurs in the coastal areas of Maranhão and Piaui, and in the forests of northeastern Pará. Also it has been collected commonly in campos in the Obidos area near Monte Alegre and Aleirim. It occurs relatively frequently in the terra firme forests near Santarém and Manaus, along the Rio Madeira, and in the northern part of Roraima. Hymenaea parvifolia is most commonly an emergent tree on sandy soil in terra firme forests (Fig. 6); however, it also occurs as small individuals in secondary forests (capo eiros) or in campos.

\section{Hymenaea courbaril, L.}

(Sp. PI. 1192, 1753)

Hymenaea courbaril is the most widely distributed species in the genus, having a range almost coincident with that of the entire genus. Hymenaea courbaril, morphologically typical of sect. Hymenaea, is thus separated

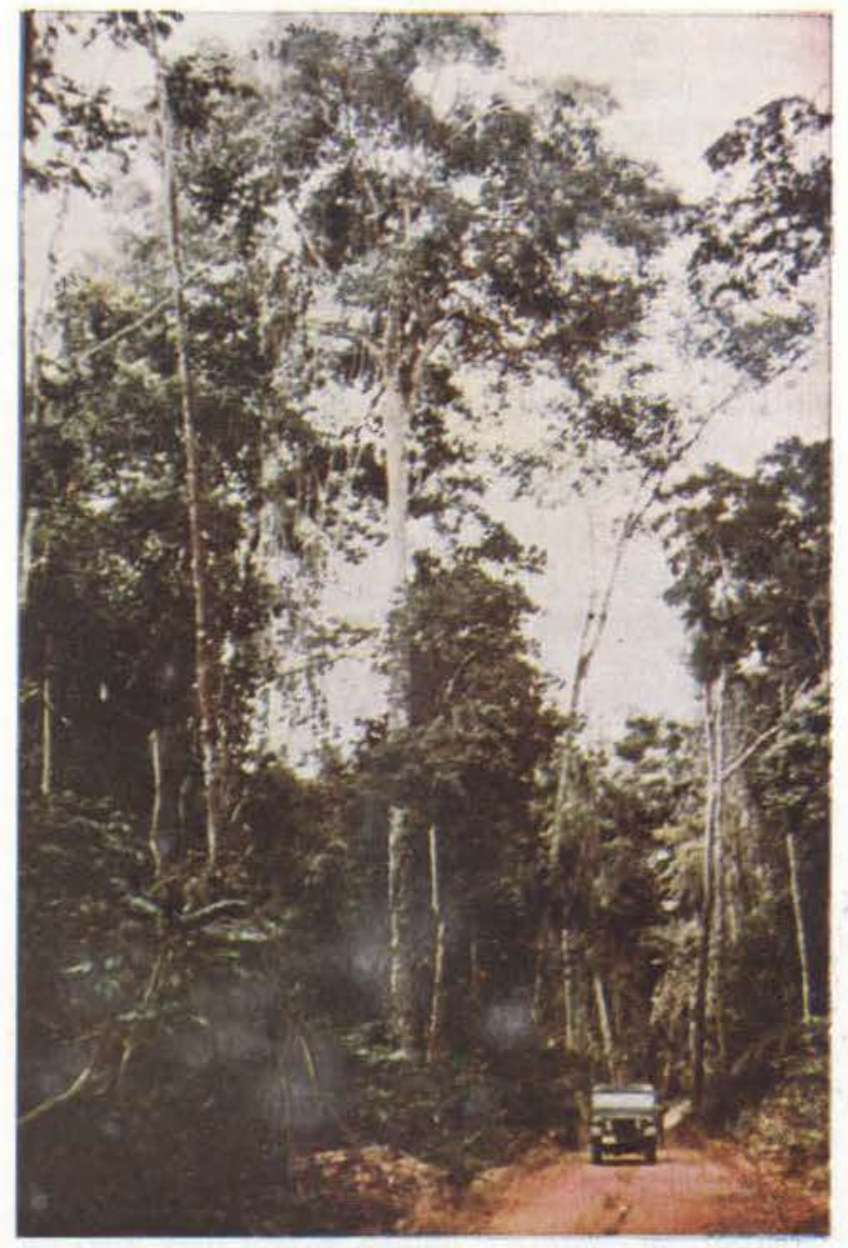

Fig. 6.- Hymenaea parvifolia on sandy terra firme in Palhão Reserve near Santarém, Pará. 
from $H$. oblongifolia and $H$. parvifolia by inflorescence, floral and fruit characters. Within this section $H$. courbaril may be separated from $H$. eriogyne and $H$. aurea by its glabrous ovary; from $\mathrm{H}$. intermedia and $H$. adenotricha by its more falcate leaflets and the large, oblong and compressed fruits: from $H$. reticulata by its relatively small and non-reticulate leaflets; from $H$. rubriflora by its glabrous leaflets and the white and ovate petals. Ecologically $H$. courbaril displays remarkable adaptability and occupies habitats ranging from caatinga (annual rainfall less than $500 \mathrm{~mm}$ ) to the Amazonian hylaea, although it is more frequent in a variety of drier ecosystems north and south of the Amazon Basin proper (Fig. 9).

Two varieties of $H$. courbaril are presently recognized: var. courbaril and var. subsessilis.
Although they are similar in their falcate leaflets, they may be distinguished from one another by the length of the stipe and the shape of their fruits. The fruits of $H$. courbaril vary (often in the same individual) in size, in degree of compression, and in color. In fact, the fruits from one of our collections from the Palhão Reserve, near Santarém, Pará, are as large as $21 \mathrm{~cm} \times 11 \mathrm{~cm} \times 4.5 \mathrm{~cm}$. the largest known. Generally, fruits of variety courbaril are longer and more compressed while in variety subsessilis they are shorter and more cylindrical. Ecological differentiation is also evident between these two varieties. Hymenaea courbaril var. courbaril is commonly found on terra firme in the Amazonian estuary. the littoral zone in Pará, and occasionally in the Central Zone (Fig. 9). In these terra firme sites it is an emergent tree, attaining such a

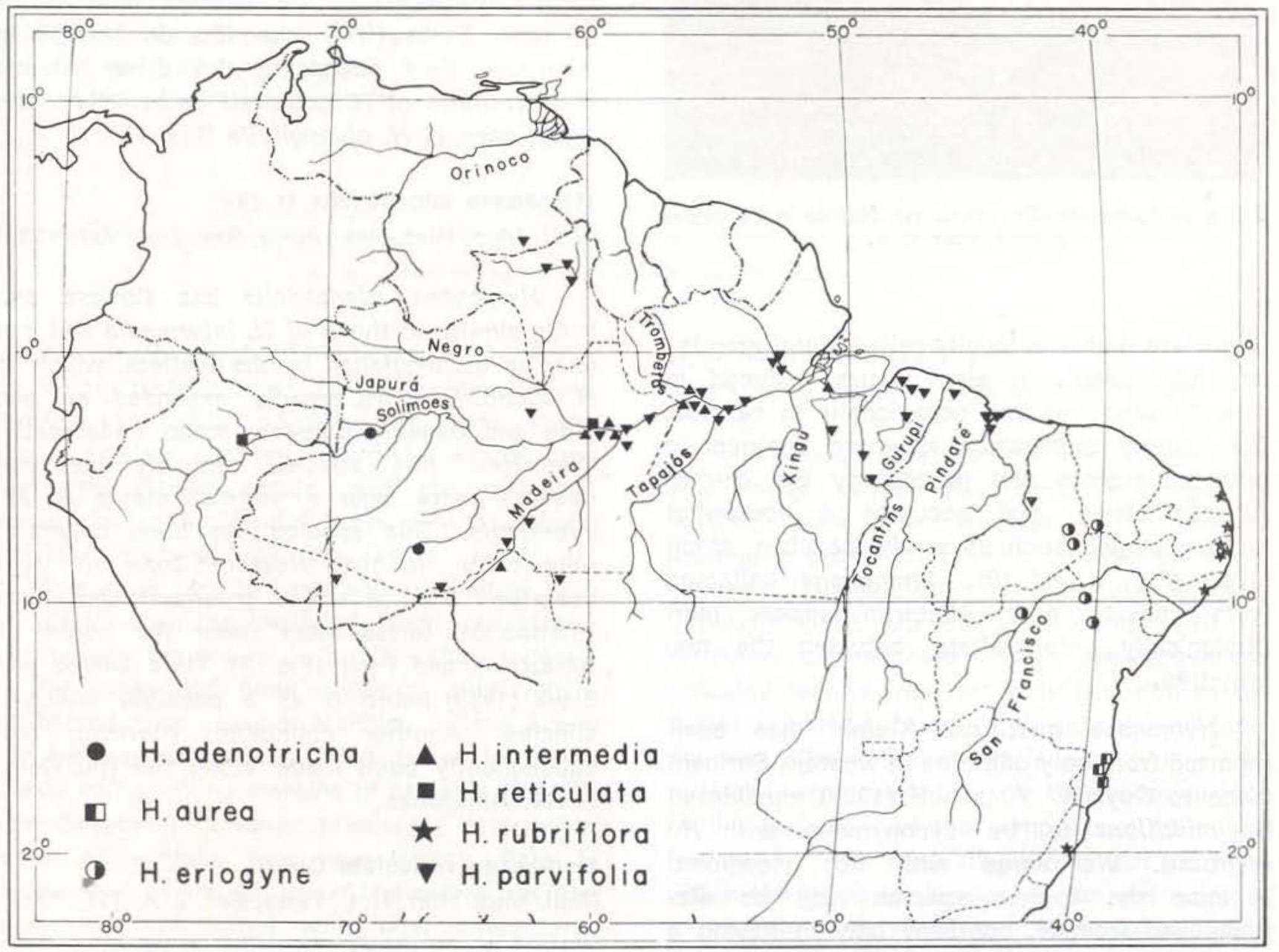

Fig. 7 - Distribution of $H$. adenotricha, $H$. aurea, $H$. ericgyne, $H$. intermedia, $H$. parvifolia, $H$, reticulcta, and $H$. rubriflora. 


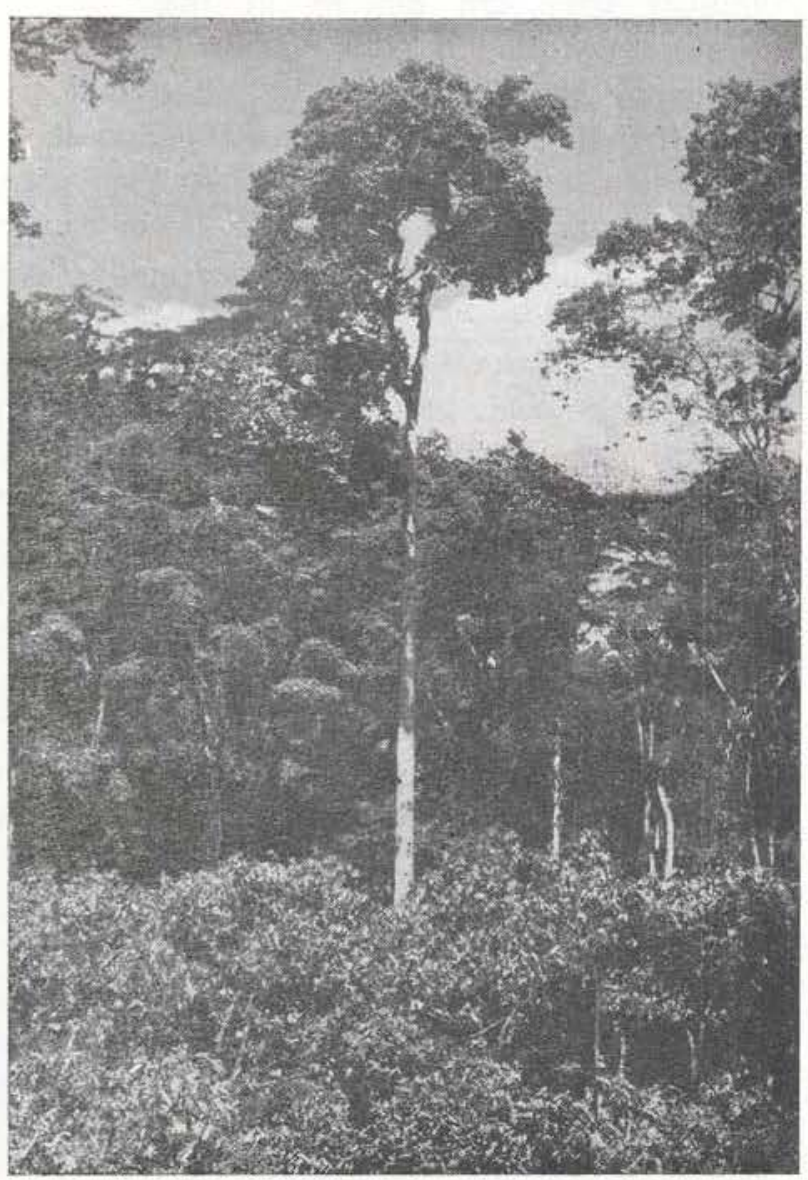

Fig. 8 - Hymenaea oblongifolia var. latifolia in the Bahian uplands near Una.

large size that it is locally called "jutai grande" or "jutaí assu". It also occurs, reduced in size, in capoeiras and occasionally in campos. The variety subsessilis is more frequent in both the eastern and particularly the central Amazon Basin, and occupies a somewhat wetter habitat, such as sandy beaches along rivers (Fig. 9 and 10). Specimens collected from campos near Almeirim appear morphologically intermediate between the two varieties.

Hymenaea multiflora Kleinh. has been reported from only one area in western Surinam close to Guyana. Amschoff (1939) considered H. multiflora to be synonymous with $H$. courbaril. We agree with her viewpoint, because the former species may be distinguished from $H$. courbaril only in having a great density of small flowers in the inflorescence.
Hymenaea courbaril var. obtusifolia, which was described by Ducke from a specimen collected from a cultivated tree (with seed source probably from llha de Marajó) in the Museu Goeldi, Belém, is morphologically so similar to the typical form that we do not now consider it a valid variety.

\section{Hymenaea intermedia Ducke}

(Arch. Jard. Bot. Rio de Janeiro 3: 92, 1922)

Hymenaea intermedia is distinguished by its intermediate position in leaf and fruit characters between $H$. courbaril and $H$. oblongifolia. It differs from $\mathrm{H}$. oblongifolia by its glabrous ovary and the densely corymbose inflorescence. It differs from $\mathrm{H}$. courbaril in having much smaller flowers, more oblong leaflets, and a relatively small few-seeded fruit, rhomboidal when fully developed. Hymenaea intermedia is an emergent tree in the primary terra firme forest in the eastern and central Amazon Basin (from the llha do Marajó to Manaus), thus occupying the drier habitats characteristic of $H$. courbaril rather than the moist ones of $\mathrm{H}$. oblongifolia (Fig. 7).

\section{Hymenaea adenotricha Ducke}

(Bull. Mus. Hist. Nat., Paris, Ser. 2, 4: 727, 1932)

Hymenaea adenotricha has flowers and fruits similar to those of $\mathrm{H}$. intermedia and can only be distinguished by the leaflets, which in $H$. adenotricha are broadly expanded on one side and densely pale-tomentose underneath. Therefore, this species probably does not deserve more than a varietal status of $H$. intermedia. This species has been collected only twice, in the Western Zone. It was described from a single emergent tree from "mattas das terras altas" near the border of Amazonas and Peru (Fig. 7). Here Ducke and Black (1953) listed it as a possible endemic species. Another collection, however, has subsequently been made along the Rio Curuquetê, Amazonas.

\section{Hymenaea reticulata Ducke}

(Bull. Mus. Hist. Nat., Paris, Ser. 2, 4: 726, 1932)

In his original description, Ducke considered Hymenaea reticulata as morphologically 


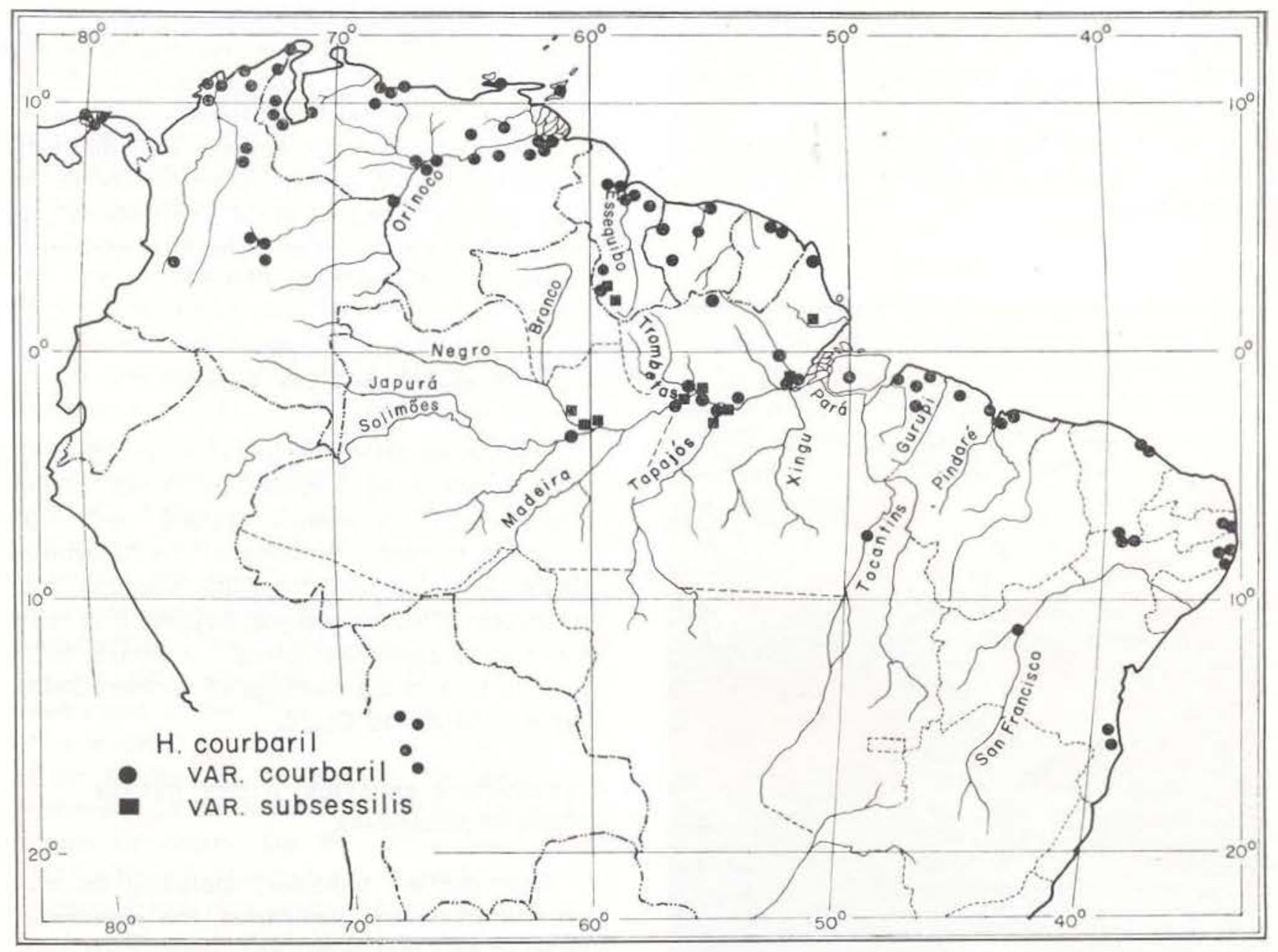

Fig. $9-$ Distribution of $H$, courbaril and its variety subsessilis.

similar to $H$. courbaril, but indicated that it could be distinguished by large leaves with densely reticulate venation on both sides, much smaller flowers, narrowly elliptic and distinctly clawed petals, and the relatively large, oblong-rhomboidal fruits with a smooth, felt-like surface. On the other hand, $H$. reticulata appears to have some affinities with $H$. rubiflora on the basis of floral characters, particularly the nature of petals. Until recently H. reticulata had been reported only from a restricted area around Manaus, where a few big trees occur in the terra firme forest on sandy soil or along margins of streams (Fig. 7). One collection, however, previously determined as $\mathrm{H}$. oblongifolia, from near Iquitos, Peru, is considểred by us to be $\mathrm{H}$. reticulata on the basis of both floral and foliar characters. Thus $H$. reticulata may occupy a wider range than has been thought.
Hymenaea rubriflora Ducke

(Mem. Inst. Oswaldo Cruz 51: 457, 1953)

Hymenaea rubriflora, the first species we will discuss whose distribution is completely isolated from the Amazon Basin, clearly belongs in sect. Hymenaea. It does not show close relationships with any particular species, although there are some affinities with $H$. reticulata as indicated above. Its uniqueness probably results from an early isolation in the Atlantic coastal forest and subsequent independent differentiation. It is distinguished by reddish-brown tomentum on the under-surface of the leaflets, and the compressed fruit with few seeds. The most distinctive feature, from which the name is derived, is the red color of the petals and filaments. This coloration is unique in the genus, as all other species have white or occasionally pale rose-colored petals 
and filaments. Until recently this species was known only from the evergreen forest near Recife, Pernambuco. It has now been collected from Rio Grande do Norte and Espirito Santo (Fig. 7). It thus has the widest distribution of Hymenaea species restricted to the Atlantic coastal forest.

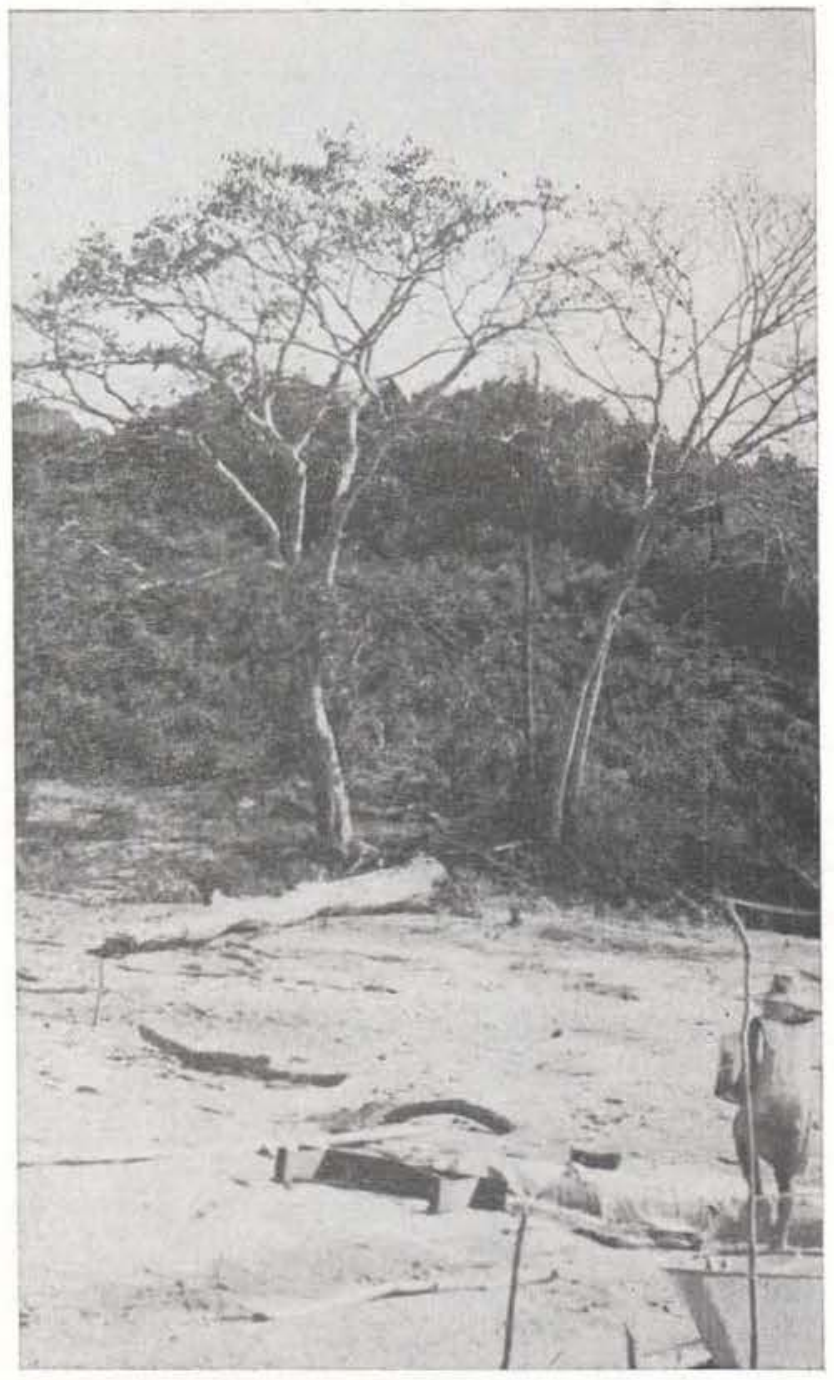

Fig, $10-$ Hymenaea courbaril var subsessilis along sandy beaches near Curuá-Una, Pará.

Hymenaea aurea Lee and Langenheim

(J. Arnold Arbor. 54(1): 96-98, 1973)

The Atlantic coastal Hymenaea aurea, like $H$. rubriflora, has no immediate relatives in the genus, perhaps also the result of early isolation and subsequent independent differentiation. Hymenaea aurea may be separated from other
Hymenaea species by the dense, golden-yellow wooly tomentum on the ovary; the large, flat fruits; the obovate-oblong leaflets which are densely golden-brown tomentose underneath and the relatively large flowers with distinctly clawed petals. $H$. aurea, known locally as "jatobá peloso" and "jatobá verdadeiro", is restricted to upland sites in coastal evergreen forests of southern Bahia (Fig. 7).

Hymenaea eriogyne Benth.

(Mart. Fl. Bras. 15(2): 237, 1870)

Hymenaea eriogyne, found in tree thickets in the caatinga of northeastern Brazil, clearly belongs by inflorescence, flower and frui: characters to sect. Hymenaea. Its Amazonian relationships, evident from its seedling type and pattern of ovary vesture, suggest it is relict from a once expanded hylaea. It occurs today as a low tree in the caatinga of northern Bahia, southern Piauí, and Ceará.

\section{REPRODUCTIVE BEHAVIOR OF THE HYLAEA SPECIES OF HYMENAEA}

Reproductive behavior, including the size of the interbreeding population, the seasons of flowering and leaf drop and their correlation with pollinating agents, and the development of fruit and dispersal of seeds, is closely tied to ecological conditions and knowledge about it is important in providing background for interpretation of speciation.

\section{THE INTERBREEDING POPULATION}

The generally low density of individuals and species within the hylaea would appear to limit the genetically effective population size, i.e., the interbreeding population, unless this dispersion can be overcome by efficient pollinating mechanisms.

Species of Hymenaea, and individuals within species, are highly dispersed in stands which we have observed in the Amazonian and Atlantic coastal forest regions. In drier ecosystems, such as semideciduous forests and savannahs, the individuals may be more abundant, even to attaining a clearcut dominance (Langenheim, 1967, 1973). Quantified 
sociologic descriptions of local Amazonian communities are rare (Black, Dobzhansky and Pavan, 1950; Pires, and Black, 1953; Takeuchi, 1961; Rodrigues, 1967), but Hymenaea species have been mentioned in two studies and generalizations from this work are pertinen: to our considerations.

Species of Hymenaea occurred in two of the four Amazonian hylaea plots studied by Black, Dobzhansky and Pavan (1950) and Pires, Dobzhansky and Black (1953). Two individuals of an unknown species of Hymenaea were present in a 3.5 hectare terra firme plot 120 $\mathrm{Km}$ from Belém (Tres de Outubro), but Hymenaea was not found in a one hectare was not found in a one hectare terra firme plot near Belém. Black, Dobzhansky and Pavan, however, indicated that they had encountered no more than half of the species in the communities they had analyzed with one hectare plots and that most of the rare, and even some of the moderately common species, were missing from their plots. Thus the size of the Belém plot may explain the absence of Hymenaea in an area and habitat where it is kriown to occur. On the other hand, three inaividuals of Hymenaea occurred in a one hectare igapó plot along the Rio Guamá near Belém. Three individuals of any species was the maximum number found in the one hectare plots; in fact, one-third of the species occurring in the one hectare plots were represented by a single individual. Two of the individuals of Hymenaea were identified as $\mathrm{H}$. parvifolia and the third was unidentified. We suspect a misidentification of $H$. parvifolia, because in our experience it does not occur in the igapó, but instead in terra firme habitats. Nonetheless, these studies point out the high degree of dispersion of Hymenaea species and of individuals within species in the communities of these terra firme and igapó habitats in the Eastern Zone.

Also, comparison of data from these 1950 and 1953 studies showed considerable differ ence in composition between the two Pará terra firme plots less than $120 \mathrm{Km}$ distant from each other. Of the 87 species found in the Belém plot and the 179 species in the Tres de Outubre plot, only 54 were in common to both. Some of the species recorded in one but not the other place are known to be widely distributed in the terra firme forests of Pará and thus the authors of these phyto-sociological papers assumed their absence to be accidental. Only a few species occurred in common to the terra firme and igapó forests where the plots were only two kilometers apart; however, the environmental conditions are strikingly different in these two habitats.

Thus data both from general observations during collection of Hymenaea species and a few quantified phytosociologic descriptions suggest that efficient pollinating and dispersal agents would probably be necessary for the success of such highly dispersed species in the Amazonian hylaea.

\section{FLOWERING, FRUTTING AND LEAF DROP}

Knowledge of the flowering period is essential to an understanding of pollinating mechanisms. Often there is an apparent relationship between flowering and vegetative activity, with flowering generally occurring when the trees are bare of leaves or at least after some leaf shed (Alvim, 1964). Beard (1946), however, indicates that among the deciduous trees of Trinidad one half flower when in leaf and fruit when bare. The othes half flower when bare, but one quarter fruit in the following dry season with the others fruiting in the following wet season.

Unfortunately, few phenological records have been kept for hylaea species. The information for Hymenaea species (Table 1) has been compiled from flowering dates given on herbarium sheets, general observations, one phenological study made at the Ducke Reserve near Manaus from 1962 to 1965 (Araujo, 1970). and from unpublished Ducke Reserve records from 1966 to 1971 (Volpato and Schmidt, pers. comm.). Only general observations are available for leaf drop, since this is primarily a relative phenomenon, with Hymenaea generally being considered "evergreen". Thus only in certain species and under certain conditions is leaf drop noteworthy.

The primary flowering time for Hymenaea species in the Amazon and adjacent basins appears to be from September to November, although in some species it either starts a 


\begin{tabular}{|c|c|c|c|c|c|c|c|c|c|c|c|c|}
\hline Species & & & & & & nths & & & & & & \\
\hline$\cdot$ & Jan & Feb & Mar & Apr & May & June & July & Aug & Sept & Oct & Nov & Dec \\
\hline \multirow{2}{*}{$\begin{array}{l}\text { H. oblongifolia } \\
\text { var. oblongifolia } \\
\text { var. palustris }\end{array}$} & & & & & & & & $\mathrm{F}$ & $\mathrm{F}$ & $\mathrm{F}$ & $\mathrm{F}$ & \\
\hline & & & & & & & & & $\mathrm{F}$ & $\mathrm{F}$ & F & \\
\hline \multirow{2}{*}{$\begin{array}{l}\text { var. latifolia } \\
\text { var. davissii }\end{array}$} & $\mathrm{F}$ & $\mathrm{F}$ & & & & & & & & & & $F$ ? \\
\hline & & & & & & $F^{*}$ & & & & & & \\
\hline H. parvifolia & & & & & & & & & F & $\mathrm{F}$ & $\mathrm{F}$ & $\mathrm{F}$ \\
\hline H. reticulata & & & & & & & & & $F$ & $\mathrm{~F}$ & $\mathrm{~F}$ & \\
\hline H. intermedia & & & & & & L & L & $\mathrm{F}$ & $\mathrm{F}$ & $\mathrm{F}$ & & \\
\hline H. adenotricha & & & & & & & $\mathrm{F}^{*}$ & $F^{\bullet}$ & & & & \\
\hline \multirow[t]{2}{*}{$\begin{array}{l}\text { H. courbaril } \\
\text { var. courbaril }\end{array}$} & & & & & & & $\mathrm{F}$ & $F$ & $\mathrm{~F}$ & $\mathrm{~F}$ & & \\
\hline & & & & & & & L & L & L & $\mathrm{F}$ & $F$ & $\mathrm{~F}$ \\
\hline H. aurea & $\mathrm{F}$ & $\mathrm{F}$ & & & & & L & L & & & & F \\
\hline H. rubriflora & $\mathrm{F}$ ? & $\mathrm{F}$ & $\mathrm{F}$ & $\mathrm{F}$ & $\mathrm{F}$ & & $\mathrm{F}$ & L & L & L & & $\mathrm{F}$ \\
\hline H. eriogyne & & $F$ & $F$ & & & & & & L & L & L & \\
\hline
\end{tabular}

Table 1 - Time of flowering and leaf drop for hylaea species of Hymenaea. $\mathrm{F}=$ flowering. $\mathrm{L}=$ leaf drop. 
little earlier or lasts a little longer (Table 1). Hymenaea courbaril var. courbaril, H. adenotricha and $\mathrm{H}$. intermedia seem to begin their flowering period earlier than $H$. parvifolia, $H$. oblongifolia var. oblongifolia and var. palustris, $H$. reticulata and even $H$. courbaril var. subsessilis. The June flowering time of $H$. oblongifolia var. davisii, known from only one collection in Guyana, is aberrant from that of the Amazonian species.

In the Atlantic coastal forests, $H$. oblongifolia var. latifolia and $H$. aurea flower in January and February, although the latter species may begin flowering slightly earlier in December. Hymenaea rubriflora apparently has a much longer period of flowering, beginning in December and continuing until May in Pernambuco where most of the collections have been made. Flowering is also recorded in July from one collection of this species from Rio Grande do Norte. However, in the caatinga region of Piaui, Hymenaea eriogyne flowers during February and March, just before the onset of the short wet season.

Ducke and Black (1953) indicate from their collecting and general observations in the Amazon Basin that flowering of trees in the terra firme forests, where there is a long. heavy rainy season and a relatively dry season: is restricted to the beginning or end of the dry season. In those parts of the hylaea where the two seasons of the year are not sharply defined and often irregular, flowering can be found in every month; in "normal" years, however, flowers are more abundant during the dry season, although, the particular schedule varies from species to species. Some do, however, flower in the rainy season. Phenological records in the Ducke Reserve study were kept only for $H$. intermedia, although general observations indicate somewhat similar patterns for $H$. parvifolia and $H$. reticulata (Volpato and Schmidt, pers. comm.). These species flowered here from August to November, in the middle of the driest season and into the transition to the wettest period, January to April (Fig. 2). The earlier flowering of $H$. courbaril var. courbaril and later flowering of $H$. courbaril var. subsessilis at present cannot be explained in terms of climatic patterns. Also from the limited data available, it appears that the várzea and igapó varieties of $H$. oblongifolia flower during the driest season (October and November) at least in the Belém area (Fig. 2). In the Western Zone, there are two distinct but shorter dry seasons in February and June to August (Fig. 2) and thus here these varieties of $H$. oblongifolia flower following the August dry season and in the transition to the wet season.

In the Atlantic coastal forests, $H$. aurea and $H$. oblongifolia var. latifolia flower in a relatively dry period from December through February before the heavy wet period from March to July; they do not, however, flower in the driest period from August to September (Fig. 2). Hymenaea rubriflora in Pernambuco starts toward the end of the dry season in December but continues well into the wet season in May.

We have observed fruit production gener. ally to be heavy where we have collected. Available fruit collections in herbaria are very poor, but we have no way to evaluate whether fruit were not often present or whether the collector was not able to obtain them. Fruit remain on the tree for at least six to eight months, but when they fall to the ground, they often are quickly attacked by microorganisms, rodents or larger mammals such as wild pigs.

The Ducke Reserve phenological studies indicate that individuals of $H$. intermedia studied there flower and fruit on a two-year cycle. Flowering occurs from August to October of alternate years with fruit maturing in the following April and May (end of the rainy season). Whether other species follow this regime in the Amazon Basin is not known. Ducke and Black (1953), however, have noted that many trees of the "interior of the virgin forest" do not flower yearly, but only at intervals of several to many years.

Although Hymenaea is usually considered to be "evergreen", most species seem to be facultatively deciduous. Richards (1966) considers any tree which is mostly bare, even for a few days, to be classified as "deciduous". He further points out that deciduous trees by this definition are numerous in all tropical rainforests. These types of deciduous trees also almost always occur in the top storey or 
are emergent trees in the rainforest. Young plants generally do not lose their leaves, but leaf drop appears to become more periodic as the tree attains maturity. Certainly, if one follows Richards' definition of "rainforest deciduousness", many species of Hymenaea would be considered to be deciduous rather than evergreen. The trees may go through a heavy le $f$ fall during dry periods and may even lose all of their leaves under severe moisture stress (Wilson, pers. comm.). Again, Araujo's (1970) phenological data for $H$. intermedia (with general observations also for $H$. parvifolia and $H$. reticulata) from the Ducke, Reserve give us important leads to behavioral activity. Apparently leaf fall varies with the flowering-fruiting cycle. In years of flowering. leaf fall immediately precedes flowering; in years of fruiting, leaf fall occurs when flowering would normally. In both cases, however, the leaves fall during the dry period from June through September. Although many leaves fall each year, these trees are rarely completely denuded because of periodic flushing. The possible exception is $H$. courbaril var. subsessilis, essentially restricted to the sandy beaches along the central Amazon, which apparently does become almost entirely defoliated from August to September. Also, Hymenaea eriogyne in the northeastern Brazi lian caatinga was completely denuded when observed during November.

We have not observed leaf drop in the Amazonian varieties of $H$. oblongifolia. In addition, in the Atlantic coastal forest, $H$. rubriflora and $H$. aurea clearly lose a great many of their leaves during the dry season, but during these periods $\mathrm{H}$. oblongifolia var. latifolia still possesses essentially a full complement of leaves.

It is unfortunate that so little data are available on leaf drop, for it appears that some species of Hymenaea behave differently from others. Leaf fall data might not only be useful in interpretating present moisture stress conditions but possibly in understanding species which had evolved mechanisms for adjusting to dry oscillations during the Pleistocene.
POLLINATING MECHANISMS AND FRUIT DISPERSAL

With the high degree of dispersion of individuals within the forest, pollinating mechanisms become critical. It has therefore been assumed that many tropical trees may be self fertile but, may also outcross when pollinators are available. Wind pollination appears to bn a rare phenomenon in the rainforest, thus the activity of insects and bats is likely to be of considerable significance.

Like most other phenomena, pollinating mechanisms have been little studied in Hymenaea. Lee (1973) has pointed out that the inflorescence and floral structure of species within the two sections may suggest different major pollinating agents. The flowers of members of sect. Trachylobium are small, and are located at the edges of a conical panicle with long, flexuous branches; these characters suggest pollination by small-sized social insects which exhibit "opportunist"-type behavior, as described by Janzen (1971b) and Baker (1973). In contrast, the flowers of species in sect. Hymenaea are larger and fewer, reach about the same level in anthesis, and are borne on short and strongly flexuous branches. These characteristics indicate the possibility of pollination predominantly by bats and larger, solitary insects with "trap-lining" behavior (Janzen, 1971b; Baker, 1973).

Information on floral behavior and pollination is presently only available from several populations of $H$. courbaril var. courbaril. Anthesis is nocturnal and Vogel (1968) has indicated that only one to five flowers in an inflorescence open at any particular time. Vogel (1968) and Frankie (pers. comm.) observed that flowers usually open at or just after sunset, between 5 and 9 p.m., and lose their calyx corolla and stamens by the following noon. Although the individual flowers are short-lived, the flowering period of a particular tree is continuous over several months. The flowers of $H$. courbaril have a strong odor and a massive nectary. This floral behavior also provides characteristics which favor bat pollination. In fact, bat visitation has been observed in $H$. courbaril by Carvalho (1960, 1961), Vogel (1968) and Frankie (pers. comm.). Carvalho observed bat visitation (Glossophaga 
soricina) of $H$. courbaril var. courbaril near Belém, whereas Vogel studied their visitation (Phyllostomus discolor) shortly after sunset to $H$. courbaril var. subsessilis near $\mathrm{Ma}$ naus. Although Vogel also observed that hummingbirds and bees visited Hymenaea flowers before sunset, and sphinx and night moths after sunset, he thought that bats were probably the most efficient transmitters of pollen. Frankie has recorded visitation of unidentified bats to $H$. courbaril var. courbaril in the seasonally dry forests of Costa Rica. Bawa (pers. comm.) has also found $H$. courbaril var. courbaril to be self-incompatible in the same Costa Rican ecosystem in which Frankie has studied bat pollination. At present no other information is available regarding compatibility in $H$. courbaril in other ecosystem types nor for any other species, and it seems improbable that the data for this one species within a single kind of ecosystem should be extrapolated for other species and ecosystems.

Early-morning visitation of insects to flowers of $H$. oblongifolia var. oblongifolia in. the Guamá Reserve near Belém has been recorded from observation towers built in the forest. Many bees and wasps have been collected but as yet are unidentified. Lee (1973) has also noted visitation of bees and butterflies to the flowers of $\mathrm{H}$. oblongifolia var. palustris and var. latifolia.

Janzen (1967) has pointed out that the coincidence of leaf shed with the peak of flowering of many trees and maximum activity of pollinating insects during the dry season in the forests of Central Amercia leads to an extremely efficient pollinating system. He further hypothesizes that this relationship between loss of leaves and peak flowering results from selection for the occurrence of pollination during the dry season at the most opportune time of the year for the activity of insects such as bees, rather than from physiological processes that could only occur at that time of year. Once a tree species has evolved such a periodicity, it would be difficult for it to break out of the pattern because of its leaving its pollinator behind and thus disrupting the reproductive process. Although leaf fall generally precedes flowering in the hylaea, where records of leaf fall are available, we would presently assume that small insect pollination would predominate only in such species as $H$. oblongifolia and $H$. parvifolia with bat pollination being more important in the species within séct. Hymenaea. However, too little information on pollinating agents is presently available to allow thinking in terms of the potentialities of phenological synchronization with insect pollination as suggested by Janzen (1969). Likewise, Alvim (1964) has clearly indicated the need for further physiological studies of the effects of total radiation, changes in radiation quality, thermoperiod, and moisture stress on the growth periodicities of tropical trees. It seems possible that both physical environmental factors as well as pollinators may be involved in this synchronization.

Dispersal of the indehiscent pods occurs commonly by water. The pods float easily and apparently in salt water, at least, remain intact for long periods of time before being attacked by microorganisms. Water dispersal probably explains the relatively frequent distribution of Hymenaea along streams. Also occurrence of $\mathrm{H}$. courbaril on islands in the West Indies and of $H$. verrucosa on African offshore islands is most likely due to water transport of the fruits, although Man may have aided in its distribution in some cases. On land, rodents and wild pigs have been observed to disperse the pods.

Seed predation is a serious problen in tropical lowland ecosystems. Janzen (1970) has even suggested that the low densities of many tropical tree species, with long distances between conspecific adults (particularly compared with temperate-zone forests), result from the action of predators on seds and seedlings. A considerable amount of work has been done regarding seed predation on leguminous species, among which has been $H$. courbaril (Janzen, 1969, 1971a). Janzen has indicated that populations from Puerto Rico and Costa Rica are free from bruchid beetle attack (common to many leguminous trees) but several species of weevils of the genus Rhinochenus oviposit on the pods of Costa Rican populations. Several mechanisms may be used by the trees to avoid such predation. First, trees in relatively dense, seasonally dry 
forest sites in Costa Rica appear to have a different reproductive pattern from those occurring in open sites. Those in the dense forest habitats have a several year (3-5) fruiting period whereas those in the open habitats may fruit in consecutive years. He suggests that the adaptive significance of sexual dormancy is in strongly reducing seed predation by Rhinochenus beetles (Janzen 1970, 1971a). This behavior of the tree means to the weevi! that seeds are three to five times as sparse as would be indicated by the total density of the adult trees. Also, where this curculenoid weevil is absent (El Salvador north through southern Mexico and in Puerto Rico), the tree usually fruits every year. The second mechanism of protection against weevil attack probably is associated with the abundant resin produced in the walls of the pods. Rehr, Bell, Janzen and Feeny (1973) have shown that the seeds of $H$. courbaril from Costa Rican and Puerto Rican populations do not contain either uncommon amino acids or alkaloids that provide protection for some tropical leguminous sceds. Therefore, they conclude that the resins in the pod walls can provide an alternative strategy to seed toxins by physically forcing out the weevil as it attempts oviposition. From our work on the chemistry of the resins, it would seem theoretically possible that a number of either chemical or physical factors relating to changes in resin composition could deter the activities of these beetles.

From our greenhouse experiments we have discovered that seeds can remain viable for at least eight years and probably longer. For the first severai years, the germination percentage is high in all of the species with which we have worked. When the seeds are older, the percentage of those which germinate decreases slightly. Scarified seeds usually germinate decreases slightly. Scarified seeds usually germinate within 10 days under favorable moisture and temperature conditions in the greenhouse or in growth chambers. Growth rates vary considerably for different species when grown under uniform environ. mental conditions, with $H$. courbaril, however always displaying the most rapid growth. Most species grow relatively rapidly immediately following germination, then go into a slow growth stage which lasts differing periods dependent upon species, before continuing more rapid activity. Rapid germination and an ability of seedlings to remain alive for a long time in slow-growing condition have been pointed out as providing survival value to species having to cope with abundant seed predators of all types (fungi, bacteria and various kinds of animals) under tropical warm and humid conditions (Richards, 1952).

RESIN PRODUCTION OF THE HYLAEA SPECIES OF HYMENAEA

Copious production of resin by the hylaea species of Hymenaea permitted its being used commercially, especially for hard varnishes, and to a limited extent for medicinal purposes. Commercial collectors valued the resin, referred to in the trade literature as "Brazilian copal", and collected it particularly in the eastern Amazon Basin where certain local populations were noted for exceptional resin yields. The factors determining resin yield have as yet not been fully determined, but it appears both genetic and environmental factors are involved. Although the resin can probably be collected from many areas in the Amazon Basin, the great collection center seems to have been around the Ilha do Marajó near Belém and along tributaries such as the Xingu and Tapajós. Hymenaea courbaril has generally been con sidered to be the most abundant resin produce of the genus, but it now seems probable that resin was collected and utilized as "Brazı! copal" from species such as $H$. oblongifolia or H. parvifolia which today at least are more common in those areas than $H$. courbaril. Resin pieces varying in size from that of a pea to that of a man's foot were often recovered from streams (Howes, 1949). Record and Hess (1943) indicate that "gatherers dig around the roots and sometimes obtain a barrelful of copal 
lumps in a place, while the former site of a tree, long since decayed, may yield several barrels of so-called fossil copal". There is no indication that the trees were tapped for the copal, nor were the legumnious Congo and Zanzibar copals obtained by tapping.

Hymenaea secretes resin by two anatomical mechanisms, either into schizogenously produced pockets surrounded by an epitheliai layer of secretory cells. or into lysigenously produced cavities resulting from the breakdown of the walls of the secretory cells (Langenheim, 1967). The schizogenous pockets form in parenchyma tissue in leaves, young stems, floral parts and fruits. In these pockets, primarily sesquiterpene hydrocarbons and a few oxygenated sesquiterpenes are present. Resin does not appear to be synthesized in young roots, but as the root and stem develop secondary tissue, resin composed primarily of diterpenoids with some sesquiterpenes is produced. The cavities into which the viscous resin is secreted may be continually increased by the lysigenous breakdown of the secretory cells, allowing the accumulation of large amounts. When a natural or manmade break in the bark occurs, the material may be exuded to the exterior of the tree. In pods, resin consisting mainly of diterpenoids and some sesquiterpenoids is produced, although its composition is quite different from that oi trunk resin. The pod resin is secreted initially into schizogenous pockets, but these can be enlarged by lysigeny when injury occurs to the fruit. Thus the pods trequently are covered by masses of resin, often filling and exuded through channels resulting from attempts by Rhinochenus beetles to penetrate the fruit.

The leaf pocket resin of all Hymenaea species we have examined is comprised of essentially the same set of sesquiterpenes, about a dozen of significance $(1 \%$ or more of the total). Caryophyllene and $a$ - and $\beta$ - selinene are usually the predominant compounds. We report the latter two com pounds together, as $a+\beta$-selinene, because there appears to be no significance to the particular isomer present, wide variations in their proportions occurring within a given population. A list of compounds with an identification number for each sesquiterpene, to be used in the figures and discussion to follow, is given in Table 2

Table 2. Leaf pocket resin sesquiterpenes in Hymenaea.

\begin{tabular}{cl} 
Compound number & \multicolumn{1}{c}{ Sesquiterpene } \\
\hline 1 & $a$ - cubebene \\
2 & $a-$ copaene \\
3 & unidentified \\
4 & $\beta-$ copaene \\
5 & caryophyllene \\
7 & $\beta-$ humulene \\
8 & $Y$ - muurolene \\
9 & $a+\beta$ - selinene \\
10 & unidentified \\
11 & $\delta$ - cadinene \\
12 & $Y$ - cadinene \\
13 & unidentified \\
14 & unidentified
\end{tabular}

Table 2 - Leaf pocket resin sesquiterpenes in Hymenaea

The remarkable consistency in leaf pocket resin chemistry among the Hymenaea species is in contrast to both qualitative and quanti. tative differences found between Hymenaea and such closely related genera as Daniellia and Guibourtia (Martin and Langenheim, unpub. data).

Within this set of sesquiterpenes common to the species of Hymenaea, quantitative composition of their leaf pocket resins shows specific differences (Figure 11). The experimental plants for this study were germinated and grown in our greenhouses under essentially identical environmental conditions. Quantitative cnalysis were made by gas chromatography of ether extracts of fresh leaves, as described elsewhere (Martin, Langenheim and Zavarin, 1973). We have analyzed these quantitative leaf pocket resin composition of Amazonian Hymenaea (Figure 11) for the relationships they suggest. We wish to emphasize however, that these data are based on seedlings grown from seed originating from a single geographic locality. The leaf pocket resin composition: data should, therefore, be considered repre. 

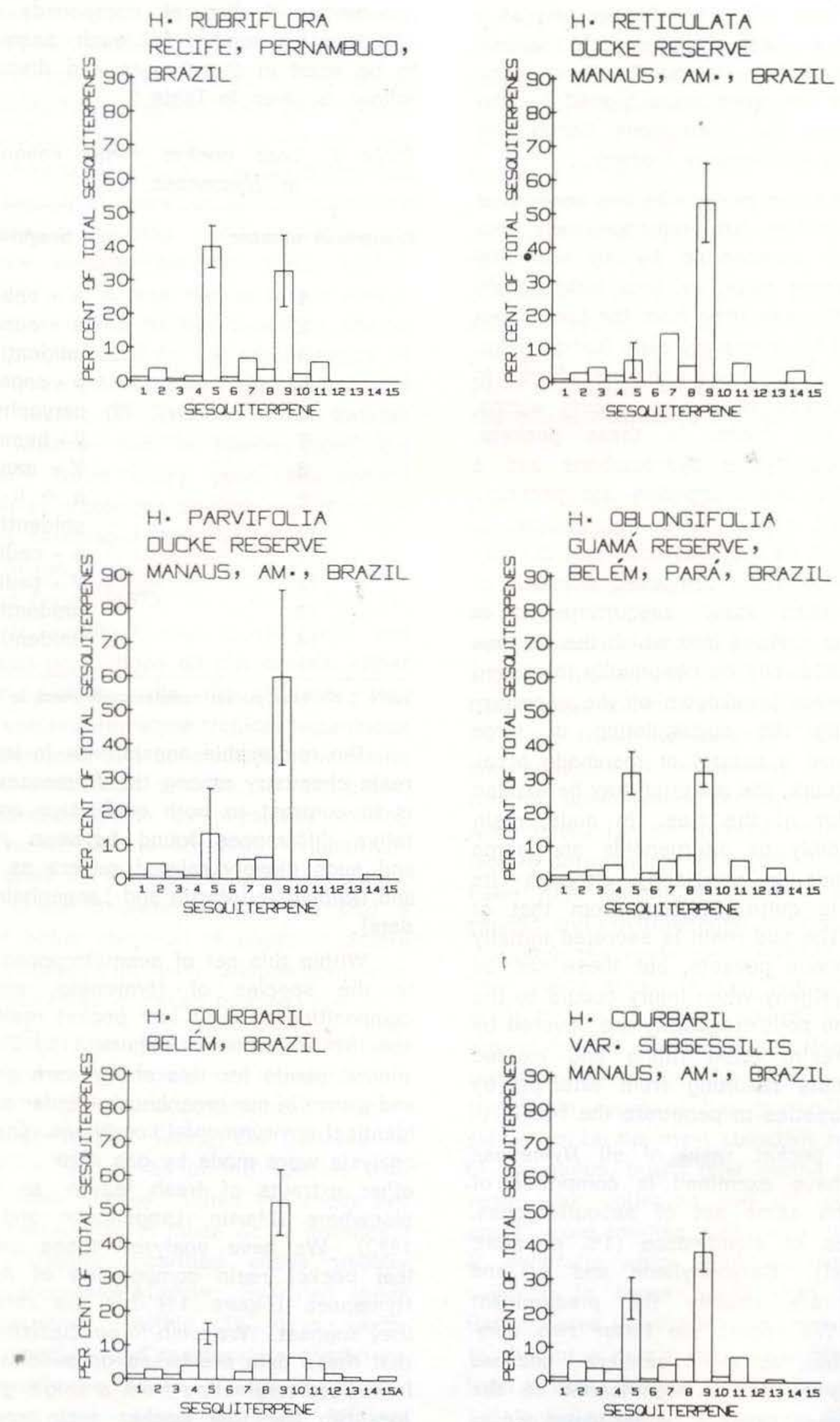

Fig. 11 - Leaf pocket resin compositions of Amazonian species of Hymenaea. Each graph shows the mzan of eight samples except $H$. reticulata ( 5 samples) and $H$. rubriflora ( 3 samples). One standard deviation above and below the mean is shown for caryophyllene and $\alpha+\beta$ selinene. 
sentative of the local population sampled rather than of an entire species.

Full details of the statistical analysis of leaf pocket resin composition among Amazonian and other Hymenaea species have been described elsewhere (Martin, 1973). To summarize briefly, an analysis of variance was performed for each sesquiterpene, excluding those present in trace amounts in all species. The ten compounds showing highly significant $(p=0.01) F$ tests in the analysis of variance were further examined by Duncan's new multiple range test to determine which species or population means were highly significantly different from one another (Steel and Torrie, 1960). This analysis indicated that no single species of the Amazonian Hymenaea is completely quantitatively different from any othe: in every compound; the underlying qualitative similarity has already been emphasized. Hymenaea reticulata is chemically the most unusual, differing from $\mathrm{H}$. oblongifolia [(and from the two African geographic populations of Hymenaea verrucosa examined (Martin, Langenheim and Zavarin, 1973)] in quantitative contents of six of the then compounds. In contrast, it differs significantly from the Manaus populations of $H$. parvifolia and $H$. courbaril var. subsessilis in content of only three of the ten sesquiterpenes.

The two geographic populations of $H$. courbaril (Belém and Curuá-Una) differ significantly only in their content of the minor compound 3. The Belém population differs from $H$. courbaril var. subsessilis in content of minor compounds 3 and 10 , while Curuá-Una $H$. courbaril differs from variety subsessilis only in compound 10 content. The close relationship among these three populations of $H$. courbari! is therefore clearly demonstrated in their leaf pocket resin chemistry.

$H$. oblongifolia differs significantly from H. courbaril var. subsessilis only in content of compound 13. Traces of this compound are present in the other species, but in $H$. oblongifolia constitutes $3.6 \%$ of the total sesquiterpenes. More differences are show by H oblôngifolia it constitutes $3.6 \%$ of the total sesquiterpenes. More differences are shown by $H$. oblongifolia in comparison with the Belém and Curuá-Una populations of $H$. courbaril, with five and three differences respectively being significant.

Further analysis of quantitative leaf pocket resin composition of these Amazonian populations of Hymenaea has been made by treating the data by the methods of numerical taxonomy to obtain coefficients of association or similarity (Sokal and Sneath, 1963). Analysis of variance weighted similarity coefficients were obtained and clustered by the single linkage method in order to more readi!y visualize the chemical relationship among the Amazonian Hymenaea species and populations (Martin, 1973). In this way, the three geographic populations of $H$. courbaril cluster together. There appears to be little difference in the grouping of the other species, although $H$. rubriflora. and $H$. parvifolia form a less well-defined group. $H$. oblongifolia and $H$. reticulata stand apart in this analysis.

We have previously suggested that Hyme. menaea oblongifolia may be the primitive stock from which many species have evolved. Because the leaf pocket resin chemistry of the Amazonian species of Hymenaea is qualitatively alike, one cannot discern evolutionary lines; clearly, however, the chemical data do not disallow the possibility that Hymenaea oblongifolia could be the parental stock. Alterations in quantitative resin composition might have accompanied processes of differentiation into specific habitats, leading to the populational and specific differences found today.

Trunk resins, usually found as solidified masses on the exterior of the tree, were the point of our initial interest in Hymenaea. It was through infrared spectral comparison of Hymenaea trunk resins with amber from Mexico, Colombia and Brazil that their amazing similarity was recognized, and Hymenaea established as the source of the fossilized resin (Langenheim, 1966, 1967, 1969). All of the Hymenaea trunk resins consist primarly of diterpenoids, with some sesquiterpenoids anci small amounts of non-terpenoid material. The diterpenoids include a series of compounds having basically similar skeletons, but repre. senting various oxidation stages : hydrocarbons, aldehydes, alcohols and acids. We have investigated primarily the resin acids, major components of the resin (20 to $38 \%$ in our 
samples) which are of special interest because they are potentially useful for chemosystematic purposes (Harborne, 1971).

Prior to our beginning work on Hymenaea trunk resins, two other groups had investigated resins of species within the genus. Nakano and Djerassi (1961) described from a commercial "Brazil copal" sample the bicyclic diterpenoid copalic acid and several double bond isomers. Another group identified eight resin acids and several neutral fraction compounds from the trunk resin of Hymenaea verrucosa, then known as Trachylobium verrucosum (Hugel, Oehlschalager and Ourisson. 1966). Excluding one sesquiterpenoid, all of these compounds were based on the bicyclic enantio-labdane skeleton. Subsequently, we have characterized from other species of Hymenaea seven enantio-labdane type resin acids (Cunningham, Martin and Langenheim $1973 \mathrm{a}$ and unpub. data), and one resin acid having the normal labdane skeleton (Cunningham, Martin and Langenheim, 1973b) Through gas chromatography of resin acid methyi esters, we have found that most of these resin acids are common to several Hymeraea species, although proportions of compounds vary enormously. Unfortunately, quantitative comparisons of resin acids in trunk samples is not justified for the following reason. Trunk resin samples as normally obtained consist of solidified masses collected from ths exterior of the tree, where they have been exposed to the atmosphere for unknown lengths of time. It is known that upon exudation, trunk resin undergoes progressive oxidation and polymerization; the exact nature and rates of these processes, their importance under varying environmental conditions, and the consequent potential compositional change in trunk resins with time are not known. This difficulty effective prohibits any detailed quantitative comparison of the trunk resins of the various Hymenaea species, although such differences are almost certainly present.

Our increasing knowledge of trunk resins of Hymenaea species has the interesting potential of soon allowing chemical comparison with the fossil resins known to originate from Hymenaea. The stability of a tunaamental istructural pattern in the resin chemistry through long periods of time is clearly reflected by the underlying similarity in resin components among species of the genus as we know it today.

\section{EVOLUTIONARY HISTORY OF THE HYLAEA} SPECIES OF HYMENAEA

Evidence from several sources supports an Africa origin for the genus Hymenaea. despite its primary distribution today being Neotropical. First, its closest relatives are the African genus Guibourtia and the Pantropical Cynometra, which has its center of diversity in Africa. Hymenaea has no evident close affinities with Neotropical genera; a close relationship to Peltogyne has been previously suggested, but Lee (1973) shows this relationship to be relatively distant. Secondly, Brenan (1965) has pointed out that $67 \%$ of the Caesalpinioideae are endemic to Africa, the most prominent components belonging within the Amherstieae-Cynometreae (Detarieae) tribal complex. Ducke and Black (1953) have further stated that the Caesalpinioideae have their secondary center of diversity in the Amazon Basin. Unfortunately, there is no accredited evidence for this tribal complex in the geologic record until the Paleocene Epoch (Germeraad Hopping and Muller, 1968; Muller, 1970). About $75 \%$ of the African Caesalpinioideae are restricted to evergreen rainforest habitats, and the sub-family likewise reaches its optimum development in the Neotropics in the Amazonian hylaea. During the Eocene Epoch, tropical rainforest vegetation reached its maximum development, probably attaining almost double the area of its present distribution (Wolfe, 1971). Thus an Early Tertiary speciation (if not origin) of the Caesalpinioideae seems likely and conditions during the Eocene were probably excellent for dispersal, With increased population size of the rainforest species, a greater number of disseminules would be supplied for dispersal, while at the same time the area suitable for colonization was larger.

Hymenaea verrucosa in eastern Africa appears to be a relict of a once more continuous distribution in evergreen rainforests across Africa, and the clear ties between the African and Amazonian species (members of sect. Trachylobium) is one of the most im- 
portant factors in considerations of the origin of the genus Hymenaea. A possible explanation for both the origin of the genus and the amphiAtlantic distribution pattern is an assumed common West Africa rainforest ancestral stock (Langenheim and Lee, 1973). Two explanations may then be presented for the Neotropic distribution: 1) union of the South American and African continents, or 2) oceanic dispersal.

Although it is assumed that Africa and South America were united, geologic evidence indicates that drifting of the two continents took place too early (around the JurassicCretaceous boundary) to explain the disjunct distribution of the New World and African species of Hymenaea or their immediate ancestors. Even if drifting occurred during the middle of the Cretaceous, as suggested by Veevers, Jones and Talent (1971) and Raven and Axelrod (1972), it is highly problematic whether any living genera of angiosperms existed at that time. Thorne (1973) also points out that the "tenous links" between tropical Africa and tropical America and the stronger floristic relationships of tropical Africa and South America to other continents rule out continental drift as a valid explanation for amphi-Atlantic disjunctions. In a careful analysis of the taxa occurring on the two continents, he believes that the distribution patterns indi cate occasional long-distance oceanic dispersai rather than retention of ancient wide ranges split by continental drift. However, migration was probably easier between the continents during late Cretaceous and early Tertiary time because long after the two continents were separated there was fairly direct access across relatively narrow seas and possibly along volcanic islands on mid-ocean ridges. Thus it seems more probable that oceanic dispersal could have occurred from the African ancestral stock during the Early Tertiary to rainforests of the New World - one sucessful establishment leading to the Cuban species $H$. torrei and another to the differentiation of the hylaea species centering around $H$. obongifolia. Subsequently the rainforest species in the New World have provided the stock for species which radiated into the drier ecosystems in drying trends during Middle to Late Tertiary time and during dry oscillations of the Pleistocene.

Paleontologic data suggest that rainfores: flora (Archangelsky, 1968) and associated faunas during the Eocene were as far south as central Patagonia on the South American cont:nent. Menéndez (1969) and Simpson (1969) present evidence from both fossil plants and mammals which indicates that strong climatic change occurred in South America during the Cenozoic, similar in mirror image to that better established in North America and other northern continents. Early in the Cenozoic Era, climatic zones were less marked than today. Typically tropical fauna, such as crocodilians and certain large snakes, occurred in areas which now are temperate. In Late Oligocene there were also arboreal mammals of subtropical to tropica! kinds, monkeys, and somewhat later anteaters and tree sloths far south of their present distribution. By the Miocene Epoch, however, the climate was on the way to drier and cooler conditions and that change, with Pleistocene fluctuations, has continued to the present.

Although the presence of rainforest vegetation in southern South America in the Early Tertiary Period and its retreat northward later in the Tertiary is generally accepted, it also has commonly been assumed that the Amazonian hylaea probably has remained relatively unaffected by climatic change. In fact, the enormous diversity of animal species in equatorial rainforests has often been explained on the basis of climatic stability through time (Darlington, 1957; Schwabe, 1969). In other words, the assumption is that communities will tend to diversify with passage of time and thus older communities will contain more species than younger ones. It also has been assumed that stable climates will permit the evolution of finer adaptations, with finer specialization allowing more different kinds of organisms to be accommodated, i.e., greater niche differrentiation (McArthur, 1969; Baker 1970).

Relatively recent evidence from a variety of sources, however, has suggested the possibility that the Amazonian hylaea may also have been disrupted by the drying tends initiated during the Miocene Epoch and by subsequent wet-dry oscillations during the Pleistocene. Sombroek (1966) has summarized geo- 
morphological and soils data from Barbosa and Ramos (1950), Wilhelmy (1952) and Ab'Saber (1959, 1967) which indicate that semi-arid climates occurred during the Miocene and Pliocene, probably resulting in "open vegetation types" in the area now occupied by hylaea. Also the hylaea was greatly restricted during the Plio-Pleistocene, when a great lake occupied most of the central area of the basin from the Andes to the Atlantic mouth of the river. Sombroek states that, during the deposition of the Pleistocene terrace materials, the Amazon valley must have had a long and pronounced dry season which limited the growth of dense vegetation, and a short and intense rainy season which created strong erosional capabilities. In the present West African rainforests, convincing geologic evidence has been found for the presence of Kalihari sands, and hence a relatively arid climate, both in Middle Pleistocene $(75,000-55,000$ years ago $)$ and later $(22,000$ years ago). This indication of aridity in the African equatorial zone during the Pleistocene (Moreau, 1966 ) adds to the credibility of such a phenomenon occurring in the Amazonian area.

Recent studies on bird, anolid lizard and lepidopteran speciation in the hylaea have resulted in an hypothesis that climatic oscillations during the Pleistocene had dramatic effects upon vegetational habitats of these organisms (Haffer, 1969; Vanzolini and Williams, 1970; Vuilleumier, 1971; Brown, 1972; Brown and Mielke, 1972; Vanozlini, 1973). The speciation model assumes at least three alternations of wet and dry periods during the last 100,000 years. During the dry phases it is hypothesized that dry-type ecosystems disrupted the hylaea, reducing it to isolated patches where conditions were relatively more favorable than over the major portion of the basin. For the forest fauna these areas acted as refuges in which populations were isolated and consequently became differentiated. In subsequent wet phases, the formerly isolated animal populations followed the spread of the forest. Where the populations met in reforested areas, complex character variation reflected the degree of genetic divergence reached during the period of isolation. Vanzolini (1973) points out that it is essential to the arguments presented for the speciation model for birds and lizards that the areas of refuge are peripheral to Amazon Basin and determined by topographic features. In other words, both Vanzolini and Haffer emphasize the repeated, relatively rapid fluctuation of hylaea between occupancy of vast areas to reduction to a few isolated peripheral patches. In fact, this peripheral location and rapidity of climatic changes appear to them to explain the great diversity of the Amazonian biota. Each new coalescence of expanding refugia would provide a complex mixing of populations that had been differentiated during isolation.

The correlations in time of the humid-arid cycles with South American glacial events remain controversial. Presently, few logical data confirm this hypothesis, although Vuilleumier (1971) suggests that future work may well document this synchronization. Paleobotanical evidence also is not available from Amazonia; however, palynological data from northern South America (van der Hammen, 1961) indicate repeated changes over large areas in the Pleistocene that do correlate with glacial events.

Only animal populations have been considered in these recent discussions of Pleitocene climatic changes affecting the Amazonian hylaea. However, wet-dry Pleistocene oscillations and their influence on vegetational changes in equatorial Africa have been discussed by Aubreville (1962). Also, Stebbins (1952) has presented a speciation model for higher plants which is applicable to the Amazonian situation. He has hypothesized that the most rapid evolution of higher plants should take place in habitats which are changing and those in which some factor is limiting. He thus thinks that many species originate under limitation of moisture and then may become readapted to moist conditions under influence of some climatic changes. In regions isolated from each other, the xerophytes continue their divergent evolution. In this way, the flora of a mesic region could contain members of the same genus or family, all adapted to essentia!ly similar conditions but adapted in different ways, and hence distinguished from each other because of different evolutionary histories. These ideas provide a speciation model for higher plants similar to those presented for the 
animals under wet-dry oscillations, and consequently expansion and contraction of rainforest and drier ecosystem types. The present floristic diversity in the Amazonian hylaea, with relatively large patches of campos and caatingas comprised of natural, non-hylaea type vegetation, campinas of specialized hylaea flora, areas of seasonally dry forests, and shrubby vegetation capping low "serras", suggest a complex history of dry climates in the past as well as the diversity of climatic and edaphic conditions today. In addition, Ducke and Black (1953) have emphasized that the presence of the same species of plants in several or many campos or campinas, which are separated by extensive areas of hylaea, implies the "remote origin" of these vegetation types.

In the evolution of Hymenaea species there appears to have been adaptive radiation from humid evergreen forest to a variety of drier ecosystem types over a wide geographic range. This differentiation was probably initiated during the Mid Tertiary drying trend and perhaps continued during periods of oscillation between wet and dry conditions during the Pleistocene. In the South American hylaea, Hymeanea species also are ecologically differentiated into several of the drier local vegetation types. One can then speculate whether or not their distribution and morphological variability give evidence for past climatic changes in the hylaea.

Species in the "Hylaea Bahiana", such as $H$. aurea, were probably initially isolated by Mid Tertiary drying trends, although there may have bsen additional modifications of this coastal habitat during marine transgressions in the Plio-Pleistocene. Elements of the older tropical flora appear to have found a refugium In the uplands where $H$. aurea occurs (Lee and Langenheim, 1973). Hymenaea eriogyne. occurring in forest patches of the caatinga of northeastern Brazil, appears to be a relict of rainforest stock isolated in extremely arid conditions. It would likewise be assumed that this differentiation probably took place during the Tertiary.

With respect to ecological differentiation within the hylaea, the distribution of the polytypic $H$. oblongifolia is especially interesting. It is the species closest to the African
$H$. verrucosa, and we assume that the two species arose from a common West African stock (Langenheim and Lee, 1973). We also have hypothesized that this species probably became establišhed during the Early Tertiary when 1) rainforest vegetation was most widespread and the probabilities for dispersal were greatest, and 2) the continents were closer together than today. In other words, we are assuming that $H$. oblongifolia was an early inhabitant of the Amazonian-type hylaea. It seems reasonable that disseminules of the present stock $H$. oblongifolia arrived from West Africa either in the region of the Amazon Basin via the South Equatorial Current or to a more southerly site via the Brazil Current. In either case, the primary distribution of the species today is represented by variety oblongifolia in the várzeas of the eastern and western zones of the Amazon Basin. The variety palustris has a similar distribution to variety oblongifolia but has differentiated into the igapó habitat. The occurrence of $H$. oblongitolia in these habitats might lend additional support to the hypothesis of its early appearance in the Amazon, as the várzea and igapó are likely to represent the oldest habitat types, existing as long as the river itself. The plants inhabiting them would also not be forced to tolerate the effects of drying conditions as much as those on the terra firme. Consequently, the ocrence of $\mathrm{H}$. oblongifolia in the complex network of igapó, várzea and terra firme in the Western Zone could have provided an ideal situation for speciation from wet to progressively drier habitats. In addition, the record of var, palustris occurring along a river near the coast of Colombia could be interpreted as indicative of a more extensive past distribution, a relict of hylaea conditions previous to the rise of the Andes in Middle Tertiary time.

Further differentiation of the $\mathrm{H}$. oblongifolia complex is represented by variety davisii in the hylaea of Guyana, where it occurs in moist sites along rivers. On the other hand, variety latifolia occurs principally in upland sites, although it alsc is found along streams in this habitat. It seems clear, therefore, from the range of habitats in which the varieties of $H$. oblongifolia occur, that it is a plastic stock in which some morphological and probably 
physiological differentiation has taken place with local ecological isolation. It has the widest distribution of any hylaea species of Hymenaea. The restriction of the varieties oblongifolia and palustris to the moist eastern and western zones of the Amazon Basin appears curious, since várzea and igapó plants are usually water dispersed and tend to occur along the length of the Amazon. Ducke and Black (1953), however, point out that some plants are distributed in the Eastern and Western Zones, but missing in the Central Zone. Whether this distributional phenomenon could be related to both lesser annual precipitation and a more pronounced dry season in the Central Zone is not known.

The only other member of sect. Trachylobium occuring in the hylaea, $H$. parvifolia, is relatively closely related to the $H$. oblongifolia complex, but apparently represents a drier habitat facies. It occurs primarily on sandy terra firme sites within the Eastern and Central Zones of Amazonia, although a few collections have been made in the Southwestern section along the upper Rio Madeira and in Acre. Considerable morphological variability characterizes the populations of $H$. parvifolia and this variability is also reflected in the quantitative sesquiterpene composition of the leaf pocket resin. Hymenaea parvifolia occurs in the campo and savannah areas more than any other hylaea species of Hymenaea than possibly $H$. courbaril var. courbaril. Its form ranges from shrub-like in the center of the campo to emergent tree in the neighboring rainforest. Apparently non-hylaea species characterize most campos; however, $H$. parvifolia occurs in both habitats. It is in these campo-hylaea areas where $H$. parvifolia displays its greatest variability. This situation may possibly fit the model suggested by Stebbins (1952).

Hymenaea courbaril has the widest distribution of any species of Hymenaea, occurring essentially over the range of the entire genus in every major ecosystem type, thus giving evidence of amazing ability to adjust to a gradient of moisture stress conditions. Hyme. naea courbaril var. courbaril seems to be less common in the Amazon Basin than in northern South America and Central America where it is very common and may even attain dominance in drier forest ecosystems. It generally seems best adapted to seasonally dry and savannah forests than to continually moist hylaea. However, specimens have been collected in several isolated pockets in the extreme northwestern and southwestern portions of the hylaea (Fig. 9). Although most of these specimens are incomplete, they appear to belong to $H$. courbaril var. courbaril. The habitat data also are poor, but several specimens clearly come from the hylaea, whereas some in Bolivia are from relatively high elevations $(900-1800 \mathrm{~m})$ on the western side of the Andes. This distribution of $H$. courbaril is particularly anomalous, since no other specimens have been collected, to our knowledge, either south or west of Manaus (Fig. 9). It does have a distribution south of the Amazon in central and eastern Brazil where considerable variation suggests new varieties may be recognized in the future. Also it appears to be the parental stock for radiation of closely related cerrado species such as $H$. stilbocarpa, H. martiana and H. stigonocarpa (Lee, 1973). In the Amazon Basin, $H$. courbaril seems best represented by its variety subsessilis, which most generally occurs along sandy beaches of tributaries in the central Amazonian region. Here it is a tree much reduced in size whicin essentially becomes denuded of its leaves during the dry season and flowers on a different schedule from variety courbaril. It coul possibly be a form which developed during a dry intervai of the Pleistocene.

Hymenaea intermedia morphologically is intermediate between $H$. oblongifolia and $H$. courbaril. Hymenaea intermedia generally occurs on terra firme in a relatively restricted area of the drier parts of the Central Zone and western part of the Eastern Zone. Ecologically $H$. intermedia is closer to $H$. courbaril than to $H$. oblongifolia. However, the closely related species $H$. adenotricha, probably best considered only a variety of $H$. intermedia, occurs on terra firme sites of the moist Western Zone. It seems possible that $H$. intermedia represents the stock most closely related to $\mathrm{H}$. oblongifolia from which the physiologically plastic $H$. courbaril cold have evolved. From its present distribution we might surmise that $H$. courbaril 
(and its closely related species in the dry ecosystem types) evolved during the drying trends of the Mid Tertiary. We have evidence for $H$. courbaril, or possibly $H$. intermedia, occurring as remains in Oligo-Miocene amber in Chiapas, Mexico (Langenheim, 1966) thus indicating a wide northern distribution at this time.

Hymenaea reticulata is thought to be related to $\mathrm{H}$. courbaril and possibly $\mathrm{H}$. rubriflora, although it is a distinctive species. It is also distinctive from all other Amazonian Hymenaea in the quantitative composition of its leaf pocket resin. Until recently, it appeared to have a very restricted distribution in relatively dry terra firme sites in the central Amazon near Manaus. An additional collection from near Iquitos, Peru, extends its range westward and possibly indicates that it was distributed more widely in the past.

Although our present evidence regarding speciation within Amazonian Hymenaea does not clearly support the hypothesis of dry oscillations during the Pleistocene which greatly restricted the Amazonian hylaea, it does not negate the possibility. Certainly there is evidence that evolution within the genus has responded to dry environmental conditions. The distribution of species is obviously related to moisture gradients and emphasizes the heterogeneity of the present environmental conditions and flora within the hylaea. The Amazonian hylaea today is definitely not a "vast uniform habitat"; in fact, as noted previously, the area of heterogeneous seasonally dry forest, savannah, campo, campina and caatinga is considerable. Even though the influence of drier climates during the Pleistocene seems likely, we would question whether the hylaea vegetation was repeatedly and rapidly restricted to small peripheral islands as suggested by Haffer (1969), Vanzolini and Williams (1970), and Vanzolini (1973). Present data from study of regeneration oi tropical rainforests indicate that primary tree species are incapable of recolonizing large areas opened at least to agriculture (GomezPompa, Vazquez-Yanes and Guevara, 1972). Also it appears that the present floras of the Amazonian campos are characterized by nonhylaea species, with little evidence of invasion of forest species into these habitats. In other words, as suggested by Gomez-Pompa, Vasquez-Pompa, Vasquez-Yanes and Guevara, the reproductive behavior of species which have evolved in the hylaea habitat makes it difficult for them to colonize open areas. They also hypothesize that as a consequence of the low population densities of rainforest species, the gene pool of these species will be greatly restricted unless large tracts of rainforests remain intact. Thus it appears from information about the ecology of rainforest tree species that speciation might be increased in dry-wet contact zones but the maintenance of the integrity of the hylaea ecosystem might demand relatively large areas of hylaea remaining even during dry Pleistocene climatic periods.

More research needs to be done regarding the role of dry environmental conditions in the evolution of hylaea species and vegetation. Hymenaea is an excellent example of a genus which probably had its origin and early history in moist rainforest conditions in Africa and South America but then differentiated in response to dry conditions within the hylaea as well as over a wide range of drier habitats both north and south of the hylaea. The evolution of some of the dry-adapted species of Hymenaea probably began in the early to middle part of the Tertiary, continued through the drying trends during that Period, and finally could have responded to dry oscillations during the Pleistocene.

\section{ACKNOWLEDGMENTS}

We wish to express our sincere appreciation to the numerous individuals who have enable this work to be carried out: Dr. Paulo de Almeida Machado, Director and Dr. William Rodrigues of INPA, Manaus, Amazonas; Dr João Murca Pires of IPEAN, Dr. Paulo Cavalcante of the Museu Goeldi, and personnel of ICOMI, Belém, Pará; and Mr. Heliomar Magnago of SUDAM, Santarém, Pará, without whose assistance the collection of specimens in the Amazonian region would no thave been possible. We owe similar thanks to Prof. Dardano Andrade-Lima, IPA, Recife, Pernambuco for aid in collecting in the northeastern area 
(Pernambuco, Paraíba, Piauí, Ceará and Bahia). and to Dr. Paulo de T. Alvim, Director, CEPEC Itabuna, Bahia for assistance in collecting in southern Bahia. We also are grateful for help provided by Dr. Luis Emygdio de Mello FiIho, Museu Nacional and Dona Graziela M Barroso, Jardim Botânico, Rio de Janeiro. Grateful acknowledgment is made to Dr. Alva Whittingham and Mr. William Stubblebine for various aspects of preparation of the manuscript and to the Maria Moors Cabot Foundation of Harvard University and the National Science Foundation (grants GB-5816, GB-13659 and GB29278) for funds to support this study.

\section{RESUMO}

O gênero Hymenaea, produtor de resina, tem uma distribuição anfi-atlântica com 13 espécies neo. trópicas e 1 africana de ocorrência ao longo de sua costa oriental. A evidência presente sugere uma origem africana do gênero com migração através do Atlântico, ocorrida durante o começo do Terciário, quando os continentes estavam mais próximos e a vegetação de mata pluvial tinha uma dispersão mui. to maior do que atualmente. O centro de sua distribuição neotrópica é a hiléia amazônica, apesar de o gênero em questão se encontrar em todos os maio. res tipos de ecossistema, dentro de sua extensa faixa que vai de $23^{\circ} \mathrm{N}$ a $28^{\circ} \mathrm{S}$. A taxonomia, ecologia, química da resina e estrutura de melhoramento genético das 9 espécies e 8 variedades de Hymenaeae das matas pluviais da Amazônia e da historicamente relacionada costa atlântica brasileira são discuti. das, como também a evolução possível destas espécies em resposta às postuladas tendências de seca iniciada no Terciário Médio e durante as oscilações de clima seco e úmido do Pleistoceno.

\section{LTTERATURE CITED}

AB'SABER, A.

1967 - Problemas geomorfológicos da Amazônia brasileira. Atas do Simpósio sóbre a Biota Amazo nica. 1: (Geociencias). Rio de Janeiro : Conselho Nacional de Pesquisas, pp. 35-62.

1968 - Pavimentos detríticos atuais e subatuas das caatingas brasileiras. Noticia Geomorfológica. Pontif. Univ. Catol. Campinas, 3: 52-54.

Alvim, P. DE T.

1964 - Tree growth periodicity in tropical climates. In : Zimmerman, M. Wood Formation. New York, Academic Press, pp. 479-495.

AMshoFf, G. J. H.

1939 - Caesalpinioideae. In: A. Pulle (Ed.), Flora of Suriname (Netherlands Guiana), 2(2): 23 .
ANDRADE-LIMA, D.

1953 - Notas sôbre a dispersão de algunas espécies vegetais no Brasil. An. Soc. Biol. Pernambuco, $11(1): 25-49$.

ARaujo, V. C. DE

1970 - Genologia de essencias florestais Amazonicas 1 . Bol. INPA; Pesquisas Florestais. 4: 1-25.

ARCHANGELSKY, S

1968 - Paleobotany and palynology in South America: A historicai review. Rev. Paleobot. Palynol., $7: 249-266$

AUBRÉVILLE, A.

1961 - Etude écologique des principales formations végétales du Brésil et contribution a la connaissance des forêts de l'Amazonian brésilienne. Nogent-sur-Manne. Centr. Tech. Forest. Trop. (Siene-France) .

1962 - Savanisation tropicale et glaciations Quaternaires. Adansonia. N S , 2(1): 16-84.

AXELROD, D. I.

1970 - Mesozoic paleogeography and early angiosperm history. Bot. Rev., 36 : 277-319.

BAKER, H. G.

1970 - Evolution in the tropics. Biotropica, 2(2): 101-111.

1973 - Evolutionary relationships between flowering planis and animals in American and African tropical forests. In : Meggers, B. J. et alii. Tropical Forest Ecosystems in Africa and South America. A Comparative Revien. Washington, D. C., Smithsonian Press, pp. 115-160.

bareosa, O. \& Ramos, J. A. R.

1959 - Território do Rio Branco (Aspectos principais da geomorfologia, da geologia e das possibilidades minerais de sua zons setentrional). Bol. Div. Geol. Mineral Dep. Nac. Prod, Mineral, Rio de Janeiro, 196 :

BEARD, J. S

1946 - The natural vegetation of Trinidad. Oxford For. Mem., 20.

Bentham, G.

1840 - Hooker's J. Bot. Kew Gard. Mise. 2 : 38-146.

BLACK, G. A. ET ALII

1950 - Some attsmpts to estimate species diversity and population density of trees in Amazonian forests. Bot. Gaz., 3: 413-425.

BRENAN, J, P. M.

1956 - The geographical relationships of the genera of the Leguminosae in tropical Africa. Webbia 19(2): $545-578$

BROWN, K. S. JR.

1972 - The Heliconians of Brazil ,Lepidptera: Nynı. phatidae). Pt. III : Ecology and biology of Heliconius natiercri, a key primitive species near extinction and comments on the evolutionary development of Heliconius and Eucides. Zoolo gica (New York Zoological Society), Spring. 
Brown, K. S. JR. \& MielKe, O. F. F.

1972 - The Heliconians of Brazil (Lepidoptera : Nymphalidade. Part. II. Introduction and general comments, with a supplementary revision of thc tribe. Zoological (New York, Zoological Society). Spring.

Candolle, A. P. de

1825 - Prodromus systematis naturalis regri vegetabilis 2. Paris, p. 94.

Carvalho, C. T. de

1960 - Das vistas de Morcegos às Flores. (Mammalis, Chiroptera). Anais Acad. Brasil Ci., 32: 359-377.

1961 - Sôbre os hábitos alimentaires de Phillostomideos (Mammalia, Chiroptera). Rev.. Bio. Trop.. 9(1) : 53-60.

CUNNINGHAM, A., ET ALII

1973a- Resin acids from two Amazonian species of Hymenaea. Phytochem., 12: 633-635.

1973b- Labd-13-en-8-ol-15-oic acid in the trunk resin of Amazonian Hymenaea courbaril. Phitochem.: (in press).

Darlington, P. J. JR.

1957 - Zoogeography: The Geographical Distribution of Animals. New York, John Wiley and Sons.

Dietz, R. A. \& Holden, J. C.

1970 - Reconstruction of Pangaea : Breakup and dispersion of continents, Permian to Present. Jour. Geophysical Research, 75(26) : 4939-4956.

DUCKE, A.

1915 - Arch. Jard. Bot., Rio de Janeiro, 1: 23.

1925 - As Leguminosas do Estado do Pará. Arch. Jard, Bot., Rio de Janeiro, 4: 283.

1930 - As Leguminosas do Estado do Pará. Supplemento Arch. Jard. Bot., V. Rio de Janeiro.

1935 - As espécies Brasileiras do jatahy, jutahy ou jatobá (gênero Hymenaea L.., Leguminosas Caesalpiniaceas). Anais Acad. Brasil Sci. 7(3): 203-211.

1949 - Notas sôbre a Flora Neotropica. II. As Leguminosas da Amazônia Brasileira. Bol. Tecn. Inst, Agron, N., Belém, Pará, 18.

DUCKE, A. \& BLACK, G. A.

1953 - Phytogeographical notes on the Brazilian Amazon. Anais Acad, Brasil Sci., 24(1) : 1-46.

EIIEN, G.

1972 - The cerrado vegetation of Brazil. Bot. Rev. $38(2): 201-341$.

FASBENDER, M. V.

1959 - Pollen grain morphology and its taxonomic significance in the Amhersitieae, Cynometreac and Sclerobieae (Caesalpiniaceae) with special reference to the American genera. Lloydia, 22(2) : 107-162.

GeRMerAad, J, H. ET ALII

1968 - Palynology of Tertiary sediments from tropical areas. Rev. Paleobot. Palynol., 6 : 189-348.
GOMEZ-POMPA, A. ET ALII

1972 - The tropical rain forest: A nonrenewable resource. Science, $177:$ 762-765.

GUNN, R.

1968 - Stranded seeds and fruits from the southeastern shore of Florida. Garden Journal (March/ April) : 43-45.

HAFFER, J.

1969 - Speciation in Amazonian forest birds. Science, 165(3889) : 131-136.

Harborne, J. B.

1971 - Terpenoid and other low molecular weight substances of systematic interest in the Leguminosae. In : Harborne, J. B. et alii (Eds.) Chemotaxonomy of the Leguminosae. London, Academic Press, pp. 257-283.

HEYWOOD, V. H.

1971 - The Leguminosae - a systematic purview. In : Harborne, J. B. et alii (Eds.). Chemotaxonomy of the Leguminosae. London, Academic Press, pp. 1-29.

HOWES, F. N.

1949 - Vegetable gums and resins. Waltham, Mass.: Chron. Bot.

HUBER, J.

1909 - Materiais para a Flora amazônica. Bol. do Museu Paraense Hist. Nat., 5 : 386.

1910 - Mattas e madeiras amazonicas. Bol. do Museu Paraense Hist. Nat., 6: 181.

HugeL, G. ET ALII

1966 - The structure and stereochemistry of diterpenes from Trachylobium verrucosum Oliv. Tetrahedron Suppl., 8, Pt. 1: 203-216.

Humboldt, A.

1807 - Essai sur ia geographie des plantes. Paris, F. Schoell.

1814-1825 — Voyage aux regions equinoxales du Nouveau Continent. Paris, F. Schoell. 3 vols.

1852 - Personal narrative of travels to the equinoctial regions of America. Transl. London, T. Ross.

JANZEN, D. H.

1967 - Synchronization of sexual reproduction of trees within the dry season in Central America. Evolution, 21 : 620-637.

1969 - Seed-eaters versus seed size, number, toxicity and dispersal. Evolution, $23: 1-27$.

1970 - Herbivores and the number of tree species in tropical forests. Amer. Naturalist, 104:501-528.

$1917 \mathrm{a}$ - Scheelea, Hymenaea and Sickingia and their seed predators. Organization for Tropical Studies News, 71(5) : 3-4.

1971b - Euglossine bees as long distance pollinators of tropical plants. Science, $171:$ 203-205.

LANGENHEIM, J. $\mathrm{H}$.

1966 - Botanical source of amber from Chiapas, Mexico. Ciencia, México, 24 : 201-211. 
1967 - Preliminary investigations of Hymenciea courbaril as a resin producer. J. Arnold Arbor., 48: 203-230.

1969 - Amber A botanical inquiry. Science, 1633 1157-1169.

1973 - Leguminous resin-producing trees in Africa and South America. In: Meggers, B. J. et alin (Eds.) - Tropical Forest Ecosystems in Africa and South America: a Comparative Review. Washington, D.C., Smithsonian Press, p: 89-104.

LANGENHEIM, J. H., ET ALII

1970 - Amazonian species of the resin-proudcing genus Hymenaea. Amer. J. Bot., 57: 754.

LANGenheim, J. H. \& Lee, Y. T.

1973 - Reinstatement of the genus Hymenaea (Le guminosae.: Caesalpinioidea) in Africa. Britto. nia, 25 : in press.

LEE, Y. T.

1973 - A sistematic study of the genus Hymenaea L. (Leguminosae, Caesalpinioideae, Detarieae). $\mathrm{Ph}$. D. dissertation, Univ. of California, Santa Cruz.

Lee, Y. T. \& Langenheim, J. H.

1973 - New taxa of the genus Hymenaea (Leguminosae: Caesalpinioideae) from Brazil and Guyana. J. Arnold Arbor., 54(1) : 94-104.

LÉONARD, J.

195\% - Genera des Cynometreae et des Amherstieae Africaines, Mem. Cl. Sci. Acad. Roy., Belgigique, $30(2): 1-314$

LIMA, P. E.

1950 - A canoal de casca de jatobá entre os índios do Xingu. Revista Museu Paulista, N.S., 4 : 369-380.

MACARTHUR, R. H.

1969 - Patterns of communities in the tropics. Biol. J. Linn. Soc., London I : 19-30.

Martin, S. S.

1973 - Characterization and comparison of leaf pocket sesquiterpenes in the genus Hymenaea L. (Leguminosae, Caesalpinioideae). $\mathrm{Ph}$. D. disser tation, Univ. of California, Santa Cruz.

Martin, S. S. \& Langenheim, J. H.

1970 - Studies of resins from Hymenaea and Trachylobium. Amer. J. Bot., 57: 756 .

MARTIN, S. S., ET ALII

1971 - Resin acids in Hymenaea (Leguminosae). Amer. J. Bot., 58: 479.

MARTIN, S. S., ET ALII

1972 - Sesquiterpenes in leaf pocket resins of Hymenaea courbaril. Phytochem., 11.: 3049-3051.

1973 - Compositional variation of leaf pocket sesquiter penes in Trachylobium verrucosum. Biochem. Syst., 1: 35-37.
MenÉndez, C. A.

1969 - Die Fossilen Floras Sudamerikas. In : Fittkau, E. F., et alii (Eds.) - Biogeography and Ecology in South America 2. The Hague, Dr. W. Junk Publs, p.: 519-561.

Ministério da Agricultura do BRASIL

(ESCRITÓRIO DE METEREOLOGIA)

1968 - Normas climatológicas, I : 1-39. Rio de Janeiro.

Moreau, R. E.

1966 - The Bird Faunas of Africa and its Islands. New York, Academic Press.

MULLER, J.

1970 - Palynological evidence on early differentiation of angiosperms. Biol. Rev. Cambridge Philo. Soc., $45: 417-450$,

Nakano, T. \& DJerassi, C.

1961 - Terpenoids. XLVI. Copalic acid. J. Org. Chem., 26: 167-173.

PIRES, J. M., ET ALII

1953 - An estimate of the number of species in an Amazonian forest community. Bot. Gaz., 6 : 467-477.

RAVEN, P. H. \& AXeLrod, D. I.

1972 - Plate tectonics and Australasian paleobiogeography.-Science, 1763 : 1379-1386.

RECORD, S. J. \& HEsS, R. W.

1943 - Timbers of the New World. New Haven, Yale University Press.

REHR, S. S., ET ALII

1973 - Insecticidal amino acids in legume seeds. Biochem. Syst., 1(1) : 63-68.

RICHARDS, P. W.

1966 - The Tropical Rain .Forest. An Ecological Study. Cambridge at the University Press.

RIZZINI, C. T.

1963 - Nota prévia sôbre divisão fitogeographica do Brasil. Revista Brasil. Geogr., 25(1) : 3-64.

1967 - Delimitação characterização e relações da flora silvestre heleiana. In : Atas do Simpósio sôbre a Biota Amazonica, 4 (Botânica) : 13-36.

RODRIGUES, W. A.

1967 - Inventário florestal pilôto ao longo da estrada Manaus-Itacoatiara, Estado do Amazonas : dadados preliminares. In: Atas do Simpósio sôbre a Biota Amazonica, 7 (Conservação da Na. tureza e Recursos Naturais) : 257-267.

SANDWITH, N. Y.

1932 - Contributions to the Flora of Tropical America VII. New and noteworthy Leguminosae and Ro saceae from British Guiana. Bull. Misc. Inform., 1931 : 366-367.

SCHULtes, R. E.

1953 - Plantae Austro-Americanae VIII de plantis principaliter callis Amazonicis novis vel criticis notae diversae. Harvard Univ. Bot. Mus, Leafl., $16(4)$ : $57-85$. 
SChWABE, G. H.

1969 - Toward an ecological characterization of the South American continent. In : Fittkau, E. F. et al. (Eds.). Biogeography and Ecology in South America 1. The Hague, Dr. W. Junk Publ., p.: 113-134.

SIMPSON, G. G.

1969 - South American mammals. In : Fitkau, E. F., et al. (Eds.). Biogeography and Ecology in South America 2. The Hague; Dr. W. Junk Publ., p.: 879-909.

SioLI, $\mathrm{H}$.

1968 - Zur Ökologie des Amazonas-gebietes. In.: Fittkau, E. F. et al. (Eds.). Biogeography and Ecology in South America 1. The Hague, Dr. W. Junk Publ., p.: 137-170.

1973 - Recent human activities in the Brazilian Amazon Region. In : Meggers, B. J. et alii (Eds.), Tropical Forest Ecosystems in Africa and South America: A Comparative Review. Washington, Smithsonian Press, p.: 321-334.

SOARES, L. DE C.

1953 - Limites meridionale e orientais da área de ocorrência da floresta amazônica em território brasileiro. Revista Brasil. Geogr., 15: 3-122.

SOKal, R. R. \& SNeath, P. H. A.

1963 - Principles of Numerical Taxonomy. San Francisco, W. H. Freeman Co.

SOMBRoEK, W. G.

1966 - Amazon soils, a reconnaissance of the soils of the Brazilian Amazon Region. Wageningen, Center for Agric. Public Documents

Steel, R. G. D. \& Torrie, J. H.

1960 - Principles and Procedures of Statistics. New York, McGraw-Hill.

Stebrins, G. L.

1952 - Aridity as a stimulus to plant evolution. Amer. Naturalist, $86(866): 33-44$.

TAKEUCHI, M.

1961 - The structure of the Amazonian vegetation II. Tropical rain forest. J. Fac. Univ. Tokyo, Sect. 3, Bot , 8(1) : 1-26.

THORNE, R. F.

1973 - Floristic relationships between tropical Africa and tropical America. In: Meggers, B. J., et alii (Eds.), Tropical Forest Ecosystems in
Africa and South America: A Comparative Reviow. Washington, D.C., Smithsonian Press, p. : $27-48$.

U. S. Dept, of Commerce (U. S. EnVironmental Data Service)

Jan. 1959 - Dec. 1969 - Monthly climatic data for the world. Washington, D. C.

VANZOLINI, P. E.

1973 - Paleoclimates, relief and species multiplication in equatorial forests. In.: Meggers, B, J. et alit (Eds.), Tropical Forest Ecosystems in Africa and South America: A Comparative Review. Washington, D. C., Smithsonian Press, p.: 255-258.

Vanzolini, P. E. \& Williams, E. E.

1970 - South American Anoles. The geographic differentiation and evolution of the Anolis crysolepsis species group (Sauria, Iguanidae). Arq. Zool. São Paulo, 19(1-2) : 1-124.

VAn Der Hammen T.

1961 - The Quarternary climatic changes of northern South America. Ann. New York Academy of Sciences, 95: 676-683.

VEEVERS, H. J. ET ALII

1971 - Indo-Australian stratigraphy and the configuration and dispersal of Gondwanaland. Nature, 229.: $383-388$.

VOGEL, S.

1968 - Chiropterophilie in der neotropischen Flora. Flora, Abt. B., 157 : 562-602.

VUILLEUMIER, B. S.

1971 - Pleistocene changes in the fauna and flora of South America. Science, 173 : 771-780.

WILHELMY, H.

1952 - Die Eiszeitliche und Nacheiszeitliche verschiebung der Klima-und-Vegetationsgrenzen in Südamerika. Frankfurt Main: Tag. Ber. U. Wiss. Abh. d. Dtsch. Geographentage 28 : 121-127.

WOLFE, J. A.

1971 - Tertiary climatic fluctuations and methods of analysis of Tertiary floras. Paleogeography, Paleoclimatol., Paleoecol. 9: 27-57. 


\section{Synoptic Key to the Hylaea Species of Hymenaea}

I. Inflorescence long-paniculate, its branches long, slender, only slightly frexuous; flowers small; ovary mostly pubescent throughout, densely hirsute at the base; fruit ovoid to obovoid, sub-compressed, 1- to few-seeded

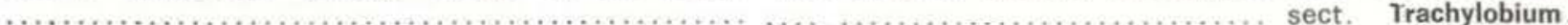

II. Petals densely pilose above; leaflets generally small, $5-8(12) \times 2.5-3.5(4.5) \mathrm{cm}$, broadly falcate $\ldots . .$.

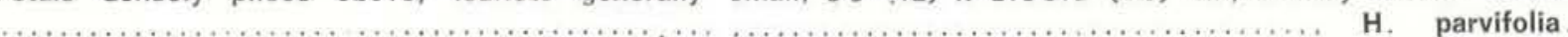

II. Petals glabrous; leaflets large, $11-15 \times 4-6 \mathrm{~cm}$, oblong to falcate

H. oblongifolia

III. Leaflets glabrous on both sides.

IV. Leaflets narrowly falcate; petals oblanceolate and subsessile; hypanthium with a stalk-like base, ca.

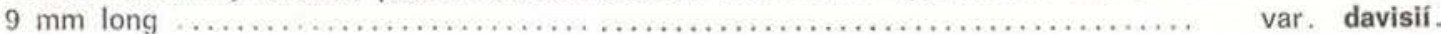

IV. i.eaflets narrowly or broadly oblong; petals subclawed to distinctly clawed; hyanpthium with a stalklike base, ca. $3 \mathrm{~mm}$ long.

$\checkmark$ Leaflets narrowly oblong (L/W ca, 2); petals sub-clawed to clawed, the claws to $2 \mathrm{~mm}$ long.

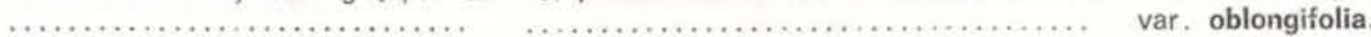

V. Leatlets broadly oblong (L/W ca, 3); petals distinctly clawed, the claws to $8 \mathrm{~mm}$ long $\ldots \ldots$.

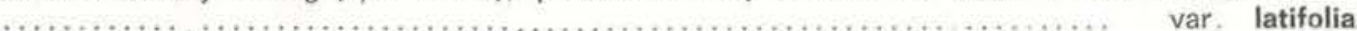

III. Leaflets densely golden-brow tomentose beneath

var. palustris.

1. Young inflorescence short-paniculate, densely corymbose when mature, its branches short, thick, strorigly flexuous; flowers large; ovary densely woolly-tomentose to glabrous; fruit obovoid, rhomboidal but mostly cylindrical to

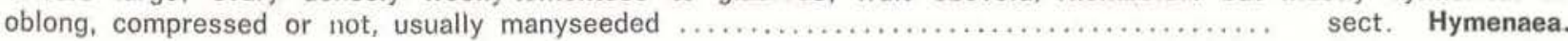

II. Ovary densely pubescent throughout; petals spatulate, distinctly clawed, the claws more than $6 \mathrm{~mm}$ long.

III. Leaflets obovate, pubescent beneath or occasionally glabrate; ovary moderately hirsute at base; fruit

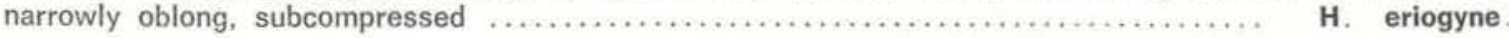

III. Leaflets obovate-oblong, densely golden - brown tomentose beneath and sparsely tomentose above; ovary

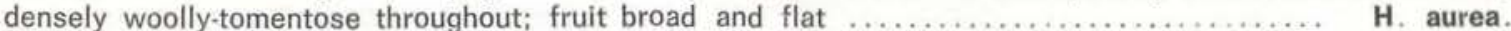

II. Ovary glabrous throughout or when young with trace of pubescence at the base; petals ovate, obovate or oblanceolate, not spatulate, sessile to subclawed, the claws less than $2 \mathrm{~mm}$ long.

IIi. Ovary borne on a slender stipe, rather small $(2 \times 2 \mathrm{~mm})$, rhomboidal; fruit ovoid or obovoid, usually rhomboidal at maturity, subcompressed; seeds 1 or 2 , rarely more.

IV. Leaflets oblong. glabrous or occasionally sparsely puberulent beneath; base straight, not rounded

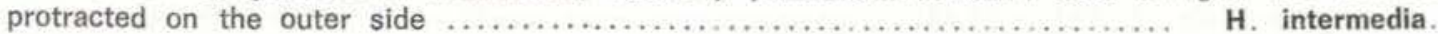

IV. Leaflets obovate, lightly to densely pubescent beneath; base rounded-protracted on the outer side... ................................. adenotricha.

III. Ovary rigidly stipitate, occasionally subsessile, oblong-oblique $(6 \times 2.5 \mathrm{~mm})$; fruit oblong to cylindrical, terete to strongly compressed; seeds $3-6$ or more.

IV. Petals narrowy oblanceolate, acute, shortly clawed, the claws ca. $2 \mathrm{~mm}$ long: leaflets slightly falcate to oblong. large, $7-18 \times 3.5-7 \mathrm{~cm}$

V. Leaflets falcate, glabrous, dull, the veinlets elevated, prominently reticulate; fruit large. rhomboidal-oblong (10-20 × 6-10 × 2.5-3.5 cm), broad, smooth (without evident resinous pockets

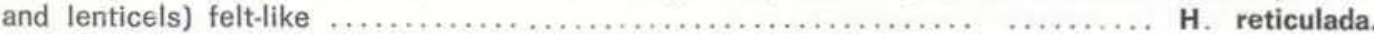

V. Leaflets oblong, sparsely pubescent, shining above, densely golden-brown tomentose beneath. the veinlets obscure; fruit small $(5-6 \times 3 \times 1.5-2 \mathrm{~cm})$, oblong, with evident resinous pockets

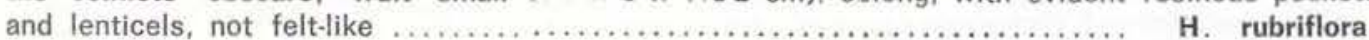

IV. Petals ovate to obovate, sessile to subsessile, rarely clawed; leaflets $\mathrm{falc}$ at e, small.

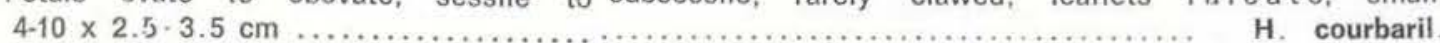

- V. Ovary with stipe $4-6(+) \mathrm{mm}$ long; leaflets broadly falcate, short-acuminate to obtuse, the base nearly straight to rounded on outer side; fruit large and oblong........ var. courbaril.

V. Ovary subsessile or with stipe ca. $2 \mathrm{~mm}$ iong: leaflets narrowly falcate short-to long acuminate, the base straight on the outer side; fruit smaller; cylindrical ............ var. subsessilis. 